\title{
Helping Business Schools Engage with Real Problems: The Contribution of Critical Realism and Systems Thinking
}

\author{
John Mingers \\ Kent Business School, University of Kent, Canterbury, UK \\ j.mingers@kent.ac.uk
}

\begin{abstract}
The world faces major problems, not least climate change and the financial crisis, and business schools have been criticised for their failure to help address these issues and, in the case of the financial meltdown, for being causally implicated in it. In this paper we begin by describing the extent of what has been called the rigour/relevance debate. We then diagnose the nature of the problem in terms of historical, structural and contextual mechanisms that initiated and now sustain an inability of business schools to engage with real-world issues. We then propose a combination of measures, which mutually reinforce each other, that are necessary to break into this vicious circle critical realism as an underpinning philosophy that supports and embodies the next points; holism and transdisciplinarity; multimethodology (mixed-methods research); and a critical and ethical-committed stance. OR and management science have much to contribute in terms of both powerful analytical methods and problem structuring methods.
\end{abstract}

Keywords: education; ethics; societal problems; soft OR; transdisciplinary; critical management

Published in the European Journal of Operational Research.

Online publication on $17^{\text {th }}$ November, 2014

http://dx.doi.org/10.1016/j.ejor.2014.10.058 


\title{
Helping Business Schools Engage with Real Problems: The Contribution of Critical Realism and Systems Thinking
}

\section{John Mingers}

Kent Business School, University of Kent, Canterbury CT7 2PE, UK

j.mingers@kent.ac.uk,01227824008

\begin{abstract}
The world faces major problems, not least climate change and the financial crisis, and business schools have been criticised for their failure to help address these issues and, in the case of the financial meltdown, for being causally implicated in it. In this paper we begin by describing the extent of what has been called the rigour/relevance debate. We then diagnose the nature of the problem in terms of historical, structural and contextual mechanisms that initiated and now sustain an inability of business schools to engage with real-world issues. We then propose a combination of measures, which mutually reinforce each other, that are necessary to break into this vicious circle critical realism as an underpinning philosophy that supports and embodies the next points; holism and transdisciplinarity; multimethodology (mixed-methods research); and a critical and ethical-committed stance. OR and management science have much to contribute in terms of both powerful analytical methods and problem structuring methods.
\end{abstract}

Keywords: education; ethics; societal problems; soft OR; transdisciplinary; critical management

\section{INTRODUCTION: THE PROBLEM}

"We shall know a little more by dint of rigour and imagination, the two great contraries of mental processes, either of which by itself is lethal. Rigor alone is paralytic death, but imagination alone is insanity." (Bateson 1980, p. 242)

The world faces many major, wicked (Rittel and Webber 1973) problems - physical, social, political at this point in time. To name but a few: climate change, the financial/economic crisis, poverty, curable disease, starvation, religious and national conflict, terrorism, unethical corporate behaviour and so on. Moreover, business and management organisations are clearly causally implicated in many of them: global warming is largely caused by industrial production and fossil fuels; the financial crisis by executive greed and lack of control and foresight; and curable disease by a reluctance to sell medicines cheaply. Yet, as has been noted (Willmott 2012), management research and the management literature, especially within business schools, remains remarkably silent about almost all of them. A very quick check in Web of Science (WoS) shows that out of 115,000 papers in 
Management (a WoS defined field) published since 1990 only $328(0.28 \%)$ were concerned with climate change, and that out of 222,500 papers in Management, Business and Finance only 292 $(0.13 \%)$ were concerned with the financial crises. Interestingly, the first paper on this subject was not published until 2008 (it was the only one in that year) which shows that there how little foresight there was before the actual events happened.

That having been said, there is at last a much greater recognition of the situation with many papers debating the 'the research/practice gap' and 'the future of the business school' as we shall see. Only very recently (December 2013), economics courses have been castigated by economists Professor Michael Joffe, (Imperial College, London) and Professor Wendy Carlin (University College London) for 'clinging to pre-crash fallacies' and 'teaching theories now known to be untrue (Inman 2013).

As Pettigrew (2011) explains, concerns about the lack of relevance and impact of social science, and particularly management, research can be traced back for many decades. In 1994, the ESRC commissioned a report (ESRC 1994) titled Building Partnerships: Enhancing the Quality of Management Research devoted to this issue, and Pettigrew's (1997) own paper, The Double Hurdle for Management Research, was itself very influential. The debate has been framed variously as mode1/ mode 2 knowledge (Gibbons et al. 1994; Tranfield and Starkey 1998), rigour/ relevance (Fincham and Clark 2009; Hodgkinson and Rousseau 2009; Kieser and Leiner 2009; Starkey and Madan 2001; Syed et al. 2009) or theory/practice gap (Khurana 2007; Reed 2009b; van de Ven and Johnson 2006) and in recent years the pace of debate has increased. Gosh et al (2010) have actually developed a statistical method for measuring the extent of the supposed gap between academic and practitioner research.

In part, this has been caused by the major and significant world problems such as climate change and the financial crisis mentioned above, and, in part, especially in the UK, by increasing pressure from institutional bodies that management research should have more impact. The Research Excellence Framework (REF) has introduced (external) impact as $20 \%$ of the overall score for research quality (HEFCE 2009), and in the US the AACSB has produced a report which highlights the isolation and lack of impact of US schools (AACSB 2008). Starkey and Tempest (2009) have suggested that we are indeed in a 'crisis' and there have been several, rather anguished, discussions of the future role of the business school in recent special issues of journals (Starkey and Tiratsoo 2007; Thomas 2011; Thomas and Cornuel 2012).

In many ways, the situation in OR/MS is a microcosm of the same problems although it was recognised much earlier. As is well known, in the 1970s Russ Ackoff (1979a; b) and C. West Churchman $(1979 ; 1994 ; 1965)$ were highly critical of the trajectory of OR away from a practical problem-solving discipline towards one of theoretical and largely impractical mathematical modelling. This led to the major developments of soft OR (Bennett 1985; Eden et al. 1983), soft 
systems (Checkland 1981; 1983; 1985; Checkland and Scholes 1990; Mingers and White 2010), problem structuring methods (Mingers and Rosenhead 2004; Rosenhead and Mingers 2001) and critical management science (Jackson 1990; 1993; Mingers 1992). Whilst these more practically oriented approaches have generally been accepted within the discipline, there still remains a major chasm between hard and soft to such an extent that the top US journals (Management Science and Operations Research) will not publish soft OR papers (Mingers 2011c) and Sodhi and Tang (2008) recently stated (ironically published in Operations Research):

"The purpose of this paper is to stimulate further discussion among OR/MS academics and practitioners on how to overcome the challenges that the OR/MS community is facing, especially in the business school. We believe that these challenges are a result of research, practice and teaching becoming increasingly disengaged from each other." (Sodhi and Tang 2008, p. 267).

In analysing this problem we shall follow a broadly soft OR approach using the 4As - Appreciation, Analysis, Assessment and Action (Mingers and Brocklesby 1997), beginning with a description and diagnosis of the problem using influence diagrams (appreciation and analysis); then making recommendations for changes that could address some of the issues identified (assessment), and finishing with a discussion of the practical problems of implementing these suggestions (action).

It should be said in some mitigation, however, that business schools generally are subjected to many, often conflicting, pressures and expectations. In most universities they are a major source of income and effectively support less wealthy departments. This requires attracting many students who often pay extremely high fees. The students in turn, especially mature students taking MBAs, can be extremely demanding and expect to be taught by staff with practical experience. At the same time, schools are expected by the university to perform well in academic research (RAE/REF in the UK) and also have to gain accreditation, often from several bodies with differing priorities. They are also expected to be active in the enterprise area, which is obviously the subject of this paper. The difficulties of trying to square all these circles will be illustrated by the example of one well-known school - Warwick Business School (WBS). This is an apt example because this was, for many years, seen as an exemplar of a successful school but recent problems there have been well documented by Parker (2014).

\section{DIAGNOSING THE PROBLEM}

There have been a number of diagnoses of the problem and corresponding solutions (Thomas 2011). We can divide the factors that have been identified into three kinds - historical factors in terms of the foundation and subsequent early development of business schools; structural factors in terms of how they are organized now, and environmental factors in terms of university strategies and wider societal forces. These are summarized in the influence diagram in Figure 1. The inner circle represents the initial historical development of business schools; the next circle represents certain aspects of the way 
schools have become structured; and the outside represents environmental factors that act to maintain and indeed exacerbate the situation.

\section{Figure 1 about here}

\subsection{Historical factors}

Positivism and impracticality: Historically, the earliest business schools began, mainly in the US, in the early part of the $20^{\text {th }}$ century (the AACSB ${ }^{1}$ was started in 1916). They were initially vocationally based, aiming at a general education for business people with little by way of research or intellectual grounding (Starkey and Tempest 2009; Thomas et al. 2013). This was highlighted in the 1959 Ford Foundation report (Gordon and Howell 1959) on business schools and the MBA. This proposed that business schools needed to gain academic rigour and credibility by moving away from the vocational emphasis towards a strong disciplinary base with an empirical and scientific grounding - essentially economics. This, according to Khurana's (2007) analysis of the fall of the business schools, was where things started to go wrong. It was based on a positivist philosophy that generated research which was rigorous in the sense of being highly quantitative and mathematical, but which was far from the practical messy problems faced by real managers (Bennis and O'Toole 2005).

Peter Checkland (Professor of Systems at Lancaster University) famously declared in 1980 that 'In 14 years as a manager, I personally was continually puzzled by the irrelevance of text-book management science to my real problems.' (Checkland 1980, p.230). Not only was it the generic reliance on positivist science that was a problem but, as Ghosal (2005) argues, it was also the specific theories that economists, particularly of the Chicago school, espoused that was in many ways responsible for the financial crisis. Writing in 2005, before the crisis had occurred, he had already identified that 'Many of the worst excesses of recent management practices have their roots in a set of ideas that have emerged from business school academics over the last 30 years' (p. 75). He gave examples such as transaction cost economics, Porter's five forces, and the use of stock options as an executive motivator.

The need for academic legitimacy was (and is still), of course, very real - as Thomas and Wilson (2012) point out even as recently as the late 1990's the foundation of a business school at Oxford University generated considerable controversy within the University.

Constructionism and irrealism: The rise of positivism and functionalism did not go unchecked, and it generated its own dialectical antithesis, especially in UK and European schools (Thomas et al. 2013), in the form of interpretivism and constructionism (and soft OR/systems in OR/MS). This development can be marked by the publication of Burrell and Morgan's (1979) seminal work on organisational

\footnotetext{
${ }^{1}$ The Association to Advance Collegiate Schools of Business is the major (US) accreditation organization for business schools. As the name suggests it was originally founded precisely to advance the standing of schools.
} 
paradigms which almost set in stone the chasm between positivism and interpretivism for the next 20 years. This work, with its insistence on paradigm incommensurability, was specifically designed to open up a legitimate space for non-traditional, i.e., non-positivist, forms of research and in this it was very successful. However, constructionism brings with it its own problems in terms of engaging with 'real-world' problems.

Although there are many forms and varieties of interpretivism/constructionism, and they vary in their ontological commitments, they generally share the view that the social world is constructed within language and discourse and this places limits on the extent to which non-discursive factors can be considered (Fairclough 2005; Thompson and Harley 2012). Durand and Vaara (2009) for example, in their paper on causation, argue that constructionism is not concerned with external causation, but solely with interpreting and understanding the views and beliefs of social actors. With such a viewpoint it is difficult to address many real-world problems other than seeing them as ultimately grounded in differences in Weltanschauungen, as does soft systems methodology (SSM) (Mingers 1984). Indeed, strong constructivists question the whole idea of an external "real world". This also leads to judgemental relativism, i.e. a stance that suggests that all viewpoints are equally valid, from which it is difficult to put forward clear proposals for change. This will be discussed more fully later. Whilst it is, of course, important that we do consider social discourse - indeed it is the starting point for organisational research - it is equally important that we do not limit ourselves to "talk and text" alone. If we do we will not be able to encompass the physical, environmental, economic, social and political factors that are an intrinsic part of the complex real-world problems of concern to us.

\subsection{Structural factors}

These historical developments can be seen to have had a series of structural consequences within the business school sector.

Lack of ethical/professional commitment: First, a serious concern that has been raised about business school activity is the lack of an ethical or moral standpoint in developing the executives and managers of the future (Ghoshal 2005; Grey 2001; 2005; Khurana 2007; Locke and Spender 2011; Mingers 2009; Mingers 2011b; Thomas et al. 2013; Weiskopf and Willmott 2013; Willmott 2011). In part, this this can be traced to the view, encapsulated by Milton Friedman (a Chicago economist!), that business did not need to have any ethical commitments: 'There is one and only one social responsibility of business - to use its resources and to engage in activities designed to increase its profits so long as it stays within the rules of the game' (Friedman 1962, p. 133). This view held sway for many years and to the extent that business schools saw themselves as working on behalf of business they felt no need to oppose it. But, more than that, both the positivist and constructivist philosophies mentioned above actually validated this stance, albeit in different ways. 
For positivists, a foundational assumption, due largely to Hume (1967 (orig. 1750)), is that facts and values must remain separated - you cannot derive an "ought" from an "is". This presumption of value-freedom is said to be one of the hallmarks of science and so clearly legitimates a research agenda that maintains that it should only consider "facts" or means to ends, but not ends in themselves - what Habermas termed "decisionism" (Habermas 1971). In practice, of course, as we shall argue later, any form of research, especially social science research, does in fact embed values and business school research has been highly committed in favour of shareholder value. Constructionists, on the other hand, can and do deal with values - they are very interested in the values of the actors that they study - but their relativist approach makes it difficult to generate an independent standpoint from which critical evaluations of ethical viewpoints could be made. Their epistemological relativism leads to a judgemental relativism that all viewpoints and Weltanschauungen have to be taken as equally legitimate.

Disciplinary compartmentalisation: Second, business schools have also become highly regimented in terms of their own internal structures which typically comprise several, often largely autonomous, sub-disciplines partly based on business functions - marketing, operations, finance, accounting, strategy, HR etc. Each group tends to construct its own discourse based on particular philosophical and methodological practices in a Kuhnian manner. As Director of a PhD Programme for many years, I had to preside at all our PhD students' upgrading presentations and almost as soon as you knew which group the student was in you could predict the form the research would take. While having a degree of disciplinary coherence can be a benefit in terms of developing the strength of the group, it is definitely a weakness for dealing with significant problems in organisations which do not split themselves up easily into 'marketing' problems or 'operations' problems. Indeed, one of the hallmarks of wicked problems is precisely their multi-dimensional nature. To give an obvious example we can consider climate change (Bhaskar et al. 2010; Newton et al. 2011). At heart this is a natural phenomenon in that it involves physical, chemical and biological processes, but in terms of its human causes, and the current (lack of) human responses, it brings in engineering, psychology, sociology, politics, operations, business strategy, logistics and many more. Tackling this requires serious transdisciplinarity, not only within the business school but also between business and other university departments, in a way that is not facilitated either by institutional structures or by disciplinary boundaries.

Impractical, unworldly curriculum: Third, the hegemony of the positivist economic model, especially in US schools which massively dominate the world rankings, has had several further unfortunate consequences. Schools have developed a very narrow focus both economically, in being driven, primarily through the MBA, to produce ever more technologically trained graduates for the finance and consultancy markets (Pfeffer and Fong 2002; 2004), and intellectually, in terms of a very tight concentration on academic journal papers rather than practical engagement (Chia and Holt 2008; 
Thomas and Wilson 2012; Wilson and McKiernan 2011; Wilson and Thomas 2012). Business schools, particularly the top ones, are driven by rankings, e.g., the Financial Times which concentrates on the MBA and particularly the earning potential of graduates. This led to a production line of graduates who had paid huge fees to gain the imprimatur of a top school in order to gain a well-rewarded job amongst similarly qualified executives based on a curriculum of largely impractical and unrealistic economic and financial models. Indeed, it has been suggested (Hodgkinson and Starkey 2011; Starkey and Tempest 2009) that it was the failure of models such as Black-Scholes that exacerbated the financial crash. Pfeffer and Fong (2002) argue that this business model is neither successful in its own terms, since there is little correlation between success in a management programme and success in business, nor in a wider sense in that it does not promote a professional ethos.

\subsection{Environmental factors}

The cash cow mentality: Environmentally, there are wider causal mechanisms at work that have reinforced or even exacerbated these trends. Business schools have been very successful and have produced huge amounts of revenue which has been extremely beneficial for their parent universities who almost universally regard business schools as cash cows, generating significant surpluses (notably through student fees not research grants) which can then be used to prop up other lesspopular subjects. So long as the fees keep rolling in, universities will be reluctant to countenance significant changes in strategy or moves that could jeopardise fee income.

Rankings fever: Academically, there has been a concentration on producing research outputs (almost exclusively papers) that can be published in what are seen as the leading world journals. This perhaps started because of the need for academic legitimacy in the early days, but it has become set in stone because of the huge increase in processes of evaluation and ranking imposed on the academic world. This takes three forms - ranking and league tables, accreditation, and assessments of research quality. Many league tables now exist, both of departments and of whole universities, such as the FT list of MBA programmes, the Times Higher and the University of Shanghai lists of world universities, and in the UK the Times, Guardian and Independent best university guides. These tend to cover a range of indicators but research is usually measured in terms of publications in top journals (Durand and McGuire 2005; Durand and Dameron 2011) and numbers of citations, or results from a specific research evaluation such as the Research Excellence Framework (REF). The other significant factor, especially in the MBA rankings, is the exit salary of students when they complete. Accreditation, which was once seen as only necessary for the lower ranked schools, is now sees as de riguer and the top schools advertise the "triple crown" of accreditation by AACSB, AMBA and EQUIS. Again, the emphasis is very much on academic research excellence rather than practical relevance. But worst of all are the specific research evaluations such as the RAE/REF in the UK (HEFCE 2007) which has 
privileged publication in the supposedly top, very academic, journals over all other forms of research output (Adler and Harzing 2009; Mingers et al. 2012; Mingers and Willmott 2013).

So, to summarise, we can see a range of synchronic and diachronic mechanisms in play which between them initiated and then maintained a situation in which it was and is very difficult for business schools to engage effectively either with their supposed target market - business and organisations - or indeed with wider society which should be the beneficiary, but which is often the victim, of their activities. We should be clear, however, that although the problem is often framed as rigour versus relevance, we do not see it as such (Syed et al. 2009). Rather, the problem is that an inappropriate definition of rigour means that much research must end up being irrelevant. With a wider and more sophisticated understanding of the nature of rigorous enquiry, research can become again both rigorous and relevant as is illustrated by the quote from Gregory Bateson above, substituting the word relevance for imagination.

\subsection{An Example: Warwick Business School}

Warwick Business School (WBS) is an insightful example of the multiple pressures faced by top schools. I have inside experience having been a student there on the first year of the Management Sciences degree (which at the time was only the second business/management degree in the country) from 1969-1972 and then being an academic from 1987 to 2003, a time of major growth and development. The Management Sciences degree was itself an example of the point made above about economics. Even at Warwick, initially the course had to be filled with large doses of economics to make it seem "academically respectable".

Warwick, as a university, was always ambitious setting out to be different and began, under its first VC Jack Butterworth, by developing close links to industry (Dyson 2004). At the time, tying academic institutions to industrial priorities was seen by many as very dangerous and undesirable, and generated student protests and a polemical book, written by the eminent historian E. P. Thompson (1970), called "Warwick University Limited". How antiquated those sentiments seem today where almost every university has its own business school! WBS was always ambitious and innovative with one of the first MBAs in the country and the most successful DL MBA. With the advent of the RAE it came to be rated as one of the top two or three research schools and was very attractive to students, academics and industrial partners. Within WBS, the expectations on staff were very high - we were expected to be excellent at teaching, research and external engagement (although not everyone actually was) and as the reputation developed a virtuous circle was set in place. Within the University, the School had at one time been rather looked down on, but its performance in successive RAEs, where it outshone more established departments such as mathematics and generated massive research income, gave it significant status and relative independence. At this time, WBS was very concerned to be engaged with external organizations, for example Pettigrew established the highly reputable Centre 
for Corporate Strategy and Change, Benington established the Local Government Research Centre and the Industrial Relations Research Unit (IRRU) worked extensively with trades unions. WBS was also the first in the UK to gain the "triple crown" of accreditations from AACSB, EFMD and AMBA.

However, beneath the successful surface there were a number of issues and conflicts. Perhaps the most important for this paper was the tension between publishing in top quality academic journals as opposed to successful business engagement and MBA teaching. The MBA (primarily the DL one) generated a significant portion of WBS income and teaching on the MBA was highly pressured, especially if student feedback was poor. This led to a polarization between the "MBA teachers" and the academic researchers with only a small number of people able to succeed in both areas (perhaps the most notable being Peter Doyle and Andrew Pettigrew). The MBA teachers tended to have significant industrial experience and maintained their links through consultancy. However, they found it difficult to publish their work in the top journals. While those who published in the $4 *$ journals could often not engage an MBA audience, nor were interested in external engagement.

A related conflict, relevant to critical management studies discussed later, was a replication of the industrial conflicts between management and unions in the 1970s and 1980s. The industrial relations group and research unit had been part of the School since its founding and were perhaps the strongest academically, gaining considerably financial support from ESRC. They generally took a critical, public management approach and supported the unions, quite the opposite of those focussed on management development and the MBA. There was considerable debate and resistance when the name was changed from School of Industrial and Business Studies to Warwick Business School.

Things came to a head in 2008 (although I had left by then), when the results of the RAE were announced, and the resulting turmoil has been well documented by Parker (2014) although clearly from a personal perspective. In the RAE, WBS came only joint fifth (with five other institutions) not making the top three for the first time. The University had a new, ambitious Vice Chancellor and the result was seen as a disaster. A new Dean of the School was appointed from outside and he set about a radical reorganization. The focus was put almost entirely on academics who could publish in the top (largely US) 4* journals (Mingers and Willmott 2013) in order to secure a better result in the REF. The result was that a significant proportion of the academic (and administrative) staff either left for other Schools or took early retirement. Whether this radical concentration on academic and theoretical research will pay off will be seen in December 2014 when the REF results are published.

\section{TOWARDS A RESOLUTION}

We have seen that this is a complex, multi-causal situation and there have been numerous suggestions as to what should be done to improve it. I wish to propose a combination of remedies that address many, although not all, of the problems and that have the merit of forming a coherent and consistent 
combination. Some of these have already been advocated individually, for example critical realism by Hodgkinson and Rousseau (2009), Hodgkinson and Starkey (2011) and Tourish (2013), and critical management studies by Delbridge (2014), but the main contribution of this paper is to demonstrate that these measures are mutually supportive and, if taken together, provide a much stronger framework of altering the focus of business school research and thus their contribution to society.

Figure 2 shows the influence diagram from Figure 1 redrawn to show how the situation could be changed with the development of these approaches. It also shows potential external changes that are discussed in the final section where we consider the possibilities for change. I will summarize the proposals briefly before discussing them in more detail in succeeding sections.

\section{Figure 2 about here}

Business school research needs to be or become:

(Critical) Realist in accepting the ontology of a causally efficacious world that is independent of us whilst recognising the epistemological limitations on our access to it.

Systemic and transdisciplinary because the world is a complex intertwining or lamination of many kinds of mechanisms - physical, biological, psychological, social, political, economic - that interact in complex, non-linear ways.

Multimethodological in that the above points imply that we need to be eclectic in our use of methods and methodologies in both research and in practical interventions. In particular, we need to combine together methods from both the empiricist and the interpretive camps in order to include both the material and social/personal worlds.

Critical and committed in recognising the unavoidable ethical and moral dimensions to all our decisions and actions, not hiding behind technocratic, managerialist or positivist arguments that they are somehow "value-free", and aiming towards improving the world for all.

For the purposes of exposition I will describe each of these characteristics separately, but in many ways their importance lies in their synergistic and complementary nature - each one, in some way, implies the others. 


\section{CRITICAL REALISM}

\subsection{The contribution of critical realism}

Critical realism (CR) has been generating significant interest in the domain of business and management research ${ }^{2}$. This is largely because it promises a way out of the sterile standoff between positivism and constructionism/ interpretivism (and later post-modernism/ post-structuralism) that has so dominated the field and led, in part, to the problems discussed above (Fleetwood and Ackroyd 2004; Kilduff et al. 2011; Mingers 2004b; Reed 1997; 2005; 2009a). CR has been proposed and discussed within particular subject areas, e.g., operational research (Mingers 2000a), information systems (Dobson 2001; Mingers 2004c; Mingers et al. 2013; Mutch 2005; Wynn and Williams 2012), marketing (Easton 2002; Easton 2010), organisation studies (Brown 2013; Delbridge and Edwards 2013; Fairclough 2005; Fleetwood 2013; Leca and Naccache 2006; Newton et al. 2011; Tourish 2013; Vincent 2008), strategy (Mir and Watson 2001; Tsang and Kwan 1999; Tsang 2013), and accounting (Modell 2009). And it has also been proposed specifically to address the rigour/relevance issue that is of concern in this paper (Hodgkinson and Starkey 2011; 2012; Syed et al. 2009; Willmott 2012).

I will not explain the basics of $\mathrm{CR}$, since that has been well done in many of the papers referenced above. But I will rather do two things: i) demonstrate how CR can help specifically with the problems outlines in the second section, and ii) discuss more recent developments in CR - the "dialectical" model - and how CR underpins the other aspects of the overall approach.

As was identified in the second section, in order to establish academic credibility business schools developed with a positivist approach based largely on economics, and an over-riding emphasis on theoretical papers published in academic journals. Later, in response to this, an alternative tradition underpinned by interpretive and constructivist philosophies arose represented in its most extreme form by the irrealism and irrationality of post-modernism and post-structuralism (Rosenau 1992). In different ways, both of these tendencies mitigate against the development of engaged, practice-based research.

Mingers (2006a) identified many problems with the positivist, economic theory, approach which can be typified by econometric forecasting. The two main ones relevant to this paper are: it reduces the notion of causality to the Humean one of constant conjunctions of events and it reduces the world that it can deal with to that of observable, empirical, quantitative data - that which cannot be quantified, cannot be. The presumption is that the world consists of stable successions of events that generate sets of measurable data over time. These can be analysed, often with very sophisticated statistical tools, to yield mathematical equations representing semi-universal laws. Causation can be no more than the

\footnotetext{
${ }^{2}$ The term "critical realism" has historically been used by other writers, for example Sellars (1916), Niiniluoto (2002) and Drake et al (1920). Generally these have similarities with particular aspect of CR but not all of it. For a discussion see Hartwig (2007, p. 96-105).
} 
statistical associations between these variables. Such a narrow approach will be of little use for many real-world problems which are characterised by complex, multi-factorial causes, lack of valid and reliable quantitative data, non-economically rational values, and open-ended and under-determined social and political processes. It is little wonder that econometric forecasting is so incredibly inaccurate (Sherden 1998; Silver 2012).

In contrast to this, CR has a complex and sophisticated approach to causality. In A Realist Theory of Science (RTS) (Bhaskar 1978), Bhaskar outlines the fundamental concepts from which the initial version of critical realism (CR) is built (developments will be discussed later). The world is taken (on the basis of transcendental arguments) to consist of structures and mechanisms that have powers and liabilities to generate the events that actually occur. These structures are distinct from the events they generate. Events occur at a particular point in time, but the structures are relatively enduring, exercising or not exercising their causal powers in interaction with each other. This gives rise to the fundamental distinction between the domains of the Real (structures and mechanisms) and the Actual (events, whether observed or not). The domain of the Empirical is the small subset of events that are in fact observed and become the basis for research. Bhaskar also recognises the distinction between closed and open systems where the former allow constant conjunctions of events, the Humean version of causality, but the latter do not. Closed systems only occur under controlled circumstances such as laboratory experiments - the social world is inherently open. The claim is also made that both nature, and our knowledge of it, are stratified and differentiated. That is, that having investigated a structure at one level, e.g., chemical reactions, we can investigate the mechanisms underlying and causing this behaviour at a deeper level, e.g., chemical valence, and so on.

Emergent properties, which go along with ontological stratification, are also defended. Bhaskar is arguing against reductionism in science. He draws the distinction between the physical laws that may underlie the possible behaviours of, say, a machine and the actual causal factors that lead to it being used in a particular way on a particular occasion. The latter cannot be explained purely in terms of the former, but come from higher-level human or economic systems. He further defends emergence, particularly opposing the cases of society being reduced to the actions of individuals, or mind being produced to neurophysiology, in The Possibility of Naturalism (Bhaskar 1979, p. 97) where he characterises his position as 'synchronic, emergent powers materialism'.

Empiricism fails to get to grips with real-world problems because of its scientistic reduction of complex multi-dimensional and multi-causal problems to that which can be measured. Constructionism fails from the opposite direction, accepting complexity and multi-dimensionality within language and discourse but eschewing the causal force of non-discursive structures. Critical realism accepts the necessity of interpretation and discourse analysis as a starting point but insists that there is an intransitive dimension of social structures and practices that exists independently of our 
conceptions of it. That actors do have complex and well-articulated conceptions of their social world, and indeed that the social world is constituted by these, does not mean that these conceptions are necessarily correct, nor that they are all equally valid. To assume that (social) being is limited by our knowledge of that being is to commit the epistemic fallacy. Equally, in recognising that social knowledge is always in some sense relative to particular temporal and cultural spaces (epistemic relativism) does not mean that we cannot have grounds for making judgements about correctness and validity.

The distinction between the transitive and intransitive aspects of knowledge is fundamental to $\mathrm{CR}$, and especially so for social science (Al-Amoudi and Willmott 2011). The intransitive is the domain of the structures or objects that may be the referents of knowledge; the transitive is the domain of discourses, conceptions and processes that can potentially generate knowledge. The social world is distinct from the natural in that it is in fact constituted by activity and discourse (the transitive) and yet becomes intransitive in that it can become an object of knowledge. Indeed, discourse itself can become an intransitive object of our research (Thompson and Harley 2012). Once it has occurred, either as talk or text (or as any other semiotic medium), we can enquire as to the grounds and conditions for these particular discourses to be produced, and also consider what effects they may have, both on other discourses and on extra-discursive practices and structures.

It is interesting to read the Editorial opening the special issue of Organization Studies on critical realism, written by Newton, Deetz and Reed (Newton et al. 2011). This is a very stimulating and wellwritten paper in which the three authors defend different positions using climate change as a case study. Newton makes the case for constructionism, recognising that constructionists range from 'mild' (who would accept that 'the material shapes the social') to 'strict' (who would 'bracket out' the reality of nature) (Burningham and Cooper 1999). It seems clear that he struggles to accept the position of the strict constructionists, concluding: 'there remains a need to account for our interaction with the materiality and biology of nature if only because it constitutes such a routine and quotidian aspect of everyday organizational life' (p. 13). CR itself would accept the 'milder' version. Deetz also defends a broadly constructionist perspective, but in his case what he calls 'relational constructionism':

'Every constructionism runs the risk of a type of impotence in the face of public controversies like the character of and the response to climate change. ... A politically attentive relational constructionism (PARC) may be a reasonable descriptive title to draw attention to features of constructionism that remain useful and viable. It does not deny the brute quality and force of the external but focusses on the manner of engagement (p. 21).

And he concludes by suggesting that critical realism and constructionism should perhaps be seen as complementary rather than contradictory. 
In general, CR's role is to serve as a philosophical underpinning for the natural and social sciences, but it does has its own theory of social agency - the transformational model of social action (TMSA) - which has been much developed by Archer (2000; 2003; 2007; Mutch 2005). Social structure preexists the activities of present social actors and provides the often-unacknowledged conditions and affordances of social activity. Equally, social activity does have effects on social structure, either maintaining it or, on occasions, transforming it, although the effects of agency are often unknown and unintended. It is important, therefore, that we maintain a distinction between a system of social structure consisting of inter-related positions and practices, and a system of intentional social action that occurs in and through the structure but is nevertheless analytically separate from it.

Thus with CR we can avoid the limitations of both empiricism and constructionism whilst still making use of them as necessary. We begin with some events or occurrences that are puzzling or unwanted and then look for causal mechanisms that might be responsible for generating or maintaining them. This may well begin with data and/or discourse but will go beyond or beneath this to try and explain the phenomena not simply record it - 'We see this approach as building a capacity for prescience rather than prediction' (Hodgkinson and Starkey 2011, p. 362.)

\subsection{Dialectical critical realism}

Critical realism is not, in fact, a single, hypostatised set of constructs, but has its own developmental history. As a minimum, we can distinguish three phases (Bhaskar and Hartwig 2010): original critical realism (Bhaskar 1978; 1979; 1986; 1989), dialectical critical realism (DCR) (Bhaskar 1993; 1994), and the spiritual turn or the philosophy of meta-reality (Bhaskar 2000; 2002a; b). Almost all the discussion of CR within business and management has been based on the original, basic model but I want to suggest that the dialectical approach has much to commend it. A good overview of these developments can be found in Bhaskar (2010).

DCR does not contradict or undermine CR, but rather situates it within a wider framework and develops the importance of a new form of critique. In CR the two primary critiques are of the epistemic fallacy (the reduction of being to the knowledge of being) and ontological actualism (the reduction of the real domain of causal mechanisms to the actual and the empirical). DCR brings in a third one - the critique of ontological monovalence or a purely positive account of reality. Put another way, DCR emphasises the role of the absent or the negative as equally important as the positive. That which does not happen (when it was expected to) is as causally efficacious as that which does; that which is present is only so because of the gaps, boundaries and spaces which differentiate one thing from another; a lack of something (e.g., food or money) is as undesired as an excess (e.g, a tsunami).

The wider framework of DCR is known as MELD and has four aspects: first Moment, second Edge, third Level and fourth Dimension. 
$1 \mathrm{M}$, the first moment, is characterised in terms of non-identity or dissimilarity, that is, being as involving many degrees of differentiation and stratification. $1 \mathrm{M}$ includes most of the distinctions from the early philosophy - transitive and intransitive, Real/Actual/Empirical; emergent powers, stratification, generative causality, and mechanisms and events. In systems terms this is all about structure.

$2 \mathrm{E}$, the second edge, is characterised in terms of negativity and absence, that is, being as process. The real consists as much of things that are not present as things that are; or, rather, things that are present, or do occur, only do so against a background of things that are not. This aspect brings in change and development for it is the need to fill an absence, or equivalently to absent an unwanted constraint or problem, that brings about occurrences and events. In systems terms, this is all about dynamics.

$3 \mathrm{~L}$, the third level, is characterised in terms of open totality, being as holistic and holistic causality. It brings in parts/wholes, inter-relations and inter-activity, recursive embeddings and reflexivity. In systems terms this is about holism and emergence.

$4 \mathrm{D}$, the fourth dimension, is concerned with transformative praxis or human agency, that is emphasising that people are causative agents who can bring about change in an intentional and purposeful way although not always one that is completely transparent to them.

These four factors generate four different emphases within an explanatory framework. 1M emphasises the complex structured nature of open systems where ontologically distinct systems, at different levels of stratification, interact with each other - what Bhaskar calls "laminated systems"(Bhaskar et al. 2010). At $2 \mathrm{E}$ we have an emphasis on the diachronic processes of change as particular laminated formations come into being, generate patterns of events, and then perhaps transform or disintegrate. At $3 \mathrm{~L}$ we have an emphasis on emergence and holistic causality by which we imply that the totality, i.e. the form or structure of the combination, causally determines the elements and the form or structure of the elements causally co-determines each other and so causally co-determine the whole (Bhaskar 1994, p. 77). At 4D we are concerned with the interaction between intentional human activity and the intransitive social structures that enable and constrain it (Mingers 2004a).

To summarise, critical realism provides an underpinning philosophy for management research that builds on the strengths of existing paradigms but avoids the problems that they engender in dealing with complex real-world problems. It links in to each of the other components of the approach as a whole: it is intrinsically systemic and transdisciplinary; it validates a mixed-methods research approach; and it has strong critical and ethical commitments. There are, of course, some criticisms and debates about critical realism - see for example Willmott (2005; 2012), Contu and Willmott (2005), Al-Amoudi and Willmott (2011), Mir and Watson (2001) and (Mingers 2004b). 


\section{SYSTEMIC AND TRANSDISCIPLINARY}

One of the most obvious characteristics of significant real-world problems is their complex, interconnected, multidisciplinary nature. In order to deal with this, we need to transcend the fragmented disciplinary silos that form the structure of most business schools. We use the term transdisciplinary in preference to multidisciplinary and interdisciplinary. Although sometimes used interchangeably, we take multidisciplinary to mean research/action involving more than one discipline each being largely separate; interdisciplinary where areas are explored that lie between conventional disciplinary boundaries; and transdisciplinary where the problems require the integration of traditional and perhaps new disciplines, and also involve both academic researchers and participants (Stock and Burton 2011). Research becomes problem driven rather than theory or data driven. Similar sentiments have been expressed by those who argue for "post-disciplinary" research such as Delbridge (2014)and Brewer (2013)

There is a discipline that has always adopted a transdisciplinary holistic approach and that is systems thinking. This has moved from biology and ecology in the 1920s (von Uexkull 1909; Woodger 1929), through cybernetics in the 1930s and 40s (Heims 1993), general systems theory (GST) in the 50s (von Bertalanffy 1971), system dynamics (Forrester 1968) and systems engineering (Hall 1962) in the 60s, into soft systems in the 70s/80s (Checkland and Scholes 1990), and critical systems in the 1980/90s ${ }^{3}$ (Jackson 1991; 2001; Mingers 1992). Although it includes many different specialisms, they are all united in employing a set of constructs and a fundamentally holistic philosophy that, if applied thoroughly, forces a researcher to approach problems in a rounded and integrative manner. It is also the case that critical realism in fundamentally systemic, implicitly perhaps in the early works but explicitly in the later dialectical phase (Mingers 2011a).

Systems thinking offers a range of concepts that can be applied within any discipline (as GST demonstrated) but it has also developed a series of practical methodologies, both hard and soft, that can assist in tackling real-world problems. From the hard end of the spectrum there are many forms of mathematical modelling, but also system dynamics that provides a practical approach to simulating complex dynamic systems (Sterman 2000) based on influence diagrams and multiple-cause diagrams. From the soft end, there are well known approaches such as soft systems methodology (SSM) (Checkland and Scholes 1990) and cognitive mapping (Eden and Ackermann 2001) which come under the general approach of problem structuring methods (Ackerman 2012; Mingers and Rosenhead 2004). And in critical systems thinking there is critical systems heuristics (Ulrich 2007), boundary critique (Midgley 2000) and creative holism (Jackson 2003). For a survey of practical applications of systems methodologies in management, see Mingers and White (2010).

\footnotetext{
${ }^{3}$ For overviews of the history of systems thinking see Checkland (1981), Capra (1997), Mingers(2006b; 2014)
} 
Being systemic and holistic necessitates transdisciplinarity, at least in dealing with real-world opensystems of social and organisational problems as opposed to the narrow and artificially constrained problems of the science laboratory. It is interesting that Newton, Deetz and Reed (2011) use the example of climate change to structure their Organization Studies Editorial introducing the special issue on critical realism because it is also the case that Bhaskar et al (2010) have recently produced a whole book titled 'Interdisciplinarity and Climate Change' which is devoted to the proposal that:

'the extensive resources of critical realism are outlined in relation to climate and its interdisciplinary nature ... Strong arguments are presented to show that critical realist approaches ... will be an indispensable part of an adequate intellectual response to climate change and the multitude of linked phenomena with which we have to deal in the twenty first century' (p. vii).

I would argue that one could swap the word 'climate' for many of the other wicked problems of today and the quote would hold true. Kilduff and Kelemen (2001) show how taking ideas from a range of disciplines, not just within a business school but across the university (e.g., philosophy) can bring novel insights and potential solutions to problems.

OR, and particularly Soft OR and systems, has always been problem-oriented and has had the capacity to bring in different disciplines as is necessary to tackle a particular problem - indeed, interdisciplinary teams was one of the hallmarks of OR when it was first developed during WW2. As well as the particular soft OR methods mentioned above, there is a significant stream of work around methodologies for dealing with complex societal problems (DeTombe 2002) including a specifically transdisciplinary approach for planning (Wiek and Walter 2009) and for sustainable development (which adopts a critical realist philosophy) (Hector et al. 2009). Complexity theory and cybernetics has also been applied to sustainability issues (Espinosa et al. 2008). What is a particularly important feature of CR is that not only can it provide an underpinning for scientific research, both natural and social, but it can also allow for and address the "extra-scientific" factors such as politics, commercial self-interest, national interests etc.

\section{MULTIMETHODOLOGICAL}

The cleavage of business school research into the positivist and interpretive paradigms had a similar effect on research methods - positivism was allied to quantitative methods and interpretivism to qualitative one, and never the twain shall meet for fear of the dreaded 'paradigm incommensurability'. However, this situation has changed significantly because of the frustrations of being forced into one camp or the other and it is now possible to suggest that mixed-methods research is becoming commonplace, indeed almost the norm. Mingers and Gill (1997) published a book on "multimethodology" in 1997. Tashakkori and Teddlie (1998) published their seminal guide to mixed methods research in 1998 and their handbook of mixed methods in 2003 (Tashakkori and Teddlie 
2003). New journals have started such as the Journal of Mixed Methods Research and the International Journal of Multiple Research Approaches, and the Mixed Methods International Research Association has been formed.

Multimethodology (Mingers 2014, Ch. 9) proposes that it is beneficial to combine together a variety of different research methods, mixing both qualitative and quantitative ones. There are at least three strong reasons for this. First, and this is justified by critical realism, the world is multi-dimensional, consisting of a variety of different kinds of systems - physical, social, conceptual, cognitive. Each has ontologically different characteristics, and different epistemological means of access. Individual research methods will only shed light on certain aspects of a complex real-world situation and so we need to combine them together to begin to get a full picture. The second reason is that research, and especially action oriented research, is not a discrete event but has several different phases within it appreciation and observation of the situation; analysis of causal mechanisms (retroduction); assessment of possible alternatives; and action to bring about change (the 4A's). Particular methods or methodologies may be more or less helpful with these various stages. For example, some methods are good at generating or capturing information but do not help with conceptualising alternatives, or bringing about commitment to change. Third, triangulation is important for effective research. Coming at a situation from a variety of different data sources, viewpoints, or research methods increases the validity of the results and often generates more interesting and unexpected insights.

We should recognise that there are costs of or barriers to mixed-methods research. As with transdisciplinarity, there are institutional barriers - departments, journals, senior academics etc - who favour, or will only accept, particular methodological approaches. There are training needs researchers have to become competent in a variety of, perhaps very different, methodologies and they may be more or less comfortable with them. In terms of the actual process, there are now a range of materials available in the literature. The Tashakkorie and Teddlie books mention above are invaluable. There are also now a range of research methods textbooks and papers that have been written specifically from a mixed methods perspective and should enable everyone to combine together quantitative and qualitative research methods in successful research and intervention. Examples are: Bryman (2006), Creswell (2009), Greene (2007), (Plowright 2011), Plano Clark (2007), and Venkatesh et al (2013). And finally the research itself may take more time or be more costly. But these are barriers that have to be overcome if research is to make the impact it should on the major problems we face.

\section{CRITICAL AND COMMITTED}

Underpinned by the Humean arguments embedded within positivism that values must be kept separate from facts, and enticed by the financial rewards of producing technically blinkered MBA graduates, business schools have, in the main, avoided any form of critical or committed stance with respect to 
management practice (Alvesson et al. 2009a; Bennis and O'Toole 2005; Contu 2009; Pfeffer and Fong 2004). But now it may be being recognised that more is needed than simply the incorporation of a business ethics module (sometimes optional!) and schools need to adopt a view towards the practice of management that recognises its potentially disastrous effects on individuals and wider communities (Antonacopoulou 2010; Ford et al. 2010). Such a position has long been articulated by what is known as critical management studies (CMS) (Alvesson et al. 2009b; Alvesson and Willmott 1992; 1996) and in this section we will discuss the contribution that can be made by critical realism, critical theory (Habermas 1993b; Mingers and Walsham 2010) and critical systems thinking (Jackson 2003; Mingers 1992). For a review of the literature of ethics and OR, see Ormerod and Ulrich (2013).

\subsection{Critical management studies}

CMS has a long, if somewhat marginal, history - one of the first papers to consider this view was that of Wood and Kelly (1978), in 1978, titled "Towards a Critical Management Science" and in 1980 Mingers (1980) was the first to recognise the relevance of the critical social theorist Jurgen Habermas. CMS draws on many traditions in critical social science (Alvesson et al. 2009a) but there is a major fault-line within it. On the one side are those, such as Fournier and Grey (2000), who view it primarily and solely as negative critique of and against management, in the manner of Adorno (1973). On the other are those, such as Alvesson and Willmott (1996), Thompson (2004), Spicer at al (2009) and Delbridge (2014), who view CMS not just as critique bur also as having the potential of developing a more enlightened and emancipatory form of management.

Fournier and Grey identify three key aspects underlying CMS - de-naturalisation, non-performativity and reflexivity. De-naturalisation means not accepting or taking for granted the current order which is often seen as 'the natural way things are'. Non-performativity means not accepting that the only valid form of knowledge is that which improves the technical efficiency of organisations rather than other aspects of their activities or social relations. Reflexivity means taking account of the fact that no theories or descriptions (including CMS) are free of the perspectives and positions of their originators.

Of these, it is non-performativity which is most contentious as it could be taken in a strong form ('anti-performativity') to be against any form of knowledge aimed at improving the performance of organisations in any dimension. Yet surely it is in all our interests that organisations such as hospitals or public services work well, and many people actually gain a lot from their work in organisations despite all the negative aspects.

Alvesson (2008) provides an alternative conceptualisation of CMS as being concerned with:

1. the critical questioning of ideologies, institutions, interests and identities

2. through negations, deconstructions, re-voicing and de-familiarisation

3. with the aim of inspiring social reform emancipation and resistance 
4. whilst appreciating peoples' work/life contexts and accepting legitimacy of organisations producing goods and services. ${ }^{4}$

We would go along with Alvesson and the others in seeing that a critically inspired management studies is aimed at bringing about a better world for all of us and this of necessity means working with organisations, not simply against them. And we suggest that critical realism, and critical theory, especially Habermas's discourse ethics, can help with this process.

\subsection{Critical realism and ethics}

Critical realism provides both sustained critiques of existing philosophical positions - positivism, constructionism and postmodernism - which in different ways refuse a critical commitment, and also strong arguments against the fact/value dichotomy and for the necessary emancipatory potential of social science. CR's view of morality (Bhaskar 1986, pp. 169; 1994, p. 107ff; Mingers 2009) has two main principles: moral realism and ethical naturalism. The idea of moral realism, which is significantly different to most other ethical theories, is that there are in fact moral truths that can be discovered and are independent of the beliefs of particular individuals or the current beliefs of particular cultures or traditions. These stem from the fundamental characteristics of human nature. Ethical naturalism means that we can actually discover what these moral truths are through social science by going from facts about the nature of society to values about how it should be. The key concept is that of 'explanatory critique'.

CR's ethical approach has four stages or arguments.

1) Social science is unavoidably value-laden not value-free (Bhaskar 1993, Ch. 3.7) Positivist science, based on Hume's law, has always held that facts must be separated from values and that one cannot derive an "ought" from an "is". But, argues CR, in fact the subject matter of social science, the actions and beliefs of the social world, are intrinsically evaluative and value laden, and nothing can, or should, be done to repair or avoid this by for example, re-describing the phenomena in neutral terms. (i) "X was murdered", and (ii) "X ceased breathing", may both be correct descriptions of the same event, but the first is to be preferred because it is more accurate - (ii) tends to carry the connotation that X died naturally; more particular - (i) implies (ii) but not vice versa; and it requires a more powerful and appropriate form of explanation - (ii) leads to a biological/medical one, (i) to a social/psychological one. Thus, social science is inevitably and properly value-full.

2) Deriving ought from is (explanatory critique) The next argument goes beyond (evaluative) description and explanation to normative implications. One of the things social science studies is social beliefs and the mechanisms that generate and sustain them. It is also in a position to judge their

\footnotetext{
${ }^{4}$ It is interesting that this formulation follows almost exactly the form of a root definition within soft systems methodology: "a system to do P by Q in order to R in the context of S" (Checkland and Scholes 1990).
} 
truth or falsity. Since the ultimate goal of science is truth, where it finds false beliefs it should expose them, and if it further finds mechanisms sustaining those false beliefs it should be committed in favour of actions that remove them.

3) Commitment to action (theory-practice consistency) (Bhaskar 1994, Ch. 7.1) So far the arguments have been at the level of social science, but what about commitments of the individual towards taking action? Here the question is one of theory-practice consistency - if one expresses a moral judgement to someone that some constraint or ill or structure is wrong, then one should be committed to changing it, or at least not taking actions that support it, in order to avoid a contradiction between beliefs and actions. This leads to the need for explanatory critique (theory), to understand the reasons for the situation, and emancipatory axiology (practice), to take action to remedy it.

4) Universalisation. (Bhaskar 1994, Ch. 5.3, Ch. 7.1 The final step is to go from addressing a particular problem or constraint to a commitment to address all such constraints. Once a commitment has been made, through a fiduciary remark, to remove a particular ill or constraint, the addressor and the addressee are logically committed to removing other similar ills and constraints and, similarly, are committed to removing constraints and ills as such, and ultimately to changing the society that maintains them. 'So the goal of universal human flourishing is implicit in every practical deed and every fiduciary remark.' [Bhaskar, 1994 \#81, p. 148)\}

I suggest that there are two main strengths of CR's ethical position: first, some of the specific arguments against value neutrality, and second the necessity of emancipatory critique. In terms of the particular arguments, I do think that 1),2) and 3) above are powerful in establishing at least the principle that social science is intrinsically and unavoidably evaluative, and thereby committed, in principle, to critique of the status quo. However, there are criticisms of these arguments discussed in Mingers (2009) and going further to practical applications is highly problematic.

In terms of emancipatory critique, this really addresses the concern of most critical or Marxist theories (or, indeed, Giddens' structuration theory), that people are not necessarily transparent to themselves, i.e., they do not fully understand their own motivations; may hold many false beliefs; and are shaped and constrained by unacknowledged structures in society. Most traditional theories of ethics - e.g., deontology, utilitarianism or contractarianism - specify how individuals should act and then presume that they will be able to do that, whereas in reality they may not (Wray-Bliss 2009). Social science thus has a role that is enlightening in revealing false beliefs and empowering in generating possible alternatives. This is a similar view of social science to that of John Brewer (2013) to be discussed later. 


\subsection{Habermas's discourse ethics}

Discourse ethics (DE) represents a fundamentally different approach to other ethical theories, be it Kantian deontology, utilitarianism/consequentialism or McIntrye's Aristotelian virtue ethics. It is distinct because it moves entirely away from considering ethical decisions to be grounded in the individual subject and instead develops a process, based on communication and discourse, for determining acceptable moral principles. This approach has, in turn, been applied at the level of the state in what is termed deliberative democracy. DE develops directly out of Habermas's theory of communicative action and only a brief summary can be given here. For more detailed explanations and applications see Habermas (1992a; 1993b), Scherer and Palazzo (2007) and Mingers (2011b) who looks at DE specifically in the context of operational research.

In considering the fundamental question of what ought we to do, Habermas distinguishes three different contexts - pragmatic contexts where the question is practical, as in how should I travel to New York? This can be seen as consequentialist. Ethical contexts, where the question is deeper and concerns the core values and self-understandings of a person or community. This can be seen as communitarian. And, finally, a small number of moral questions where the results must be seen as universal, applying to all people. This is more Kantian but with a difference. The answers to these moral questions are to be found not through individual soul-searching but through a real debate, involving, in some way, all those who are affected by the issue.

'We should not expect a generally valid answer when we ask what is good for me, or good for us, or good for them; we must rather ask: what is equally good for all? This "moral point of view" constitutes a sharp but narrow spotlight, which selects from the mass of evaluative questions those action-related conflicts which can be resolved with reference to a generalizable interest; these are questions of justice'

(Habermas 1992a, p. 248)

How should we judge if a norm is indeed universalizable? The answer is Habermas's version of Kant's categorical imperative, what he calls the discourse principle (D): 'Only those norms can claim to be valid that meet (or could meet) with the approval of all affected in their capacity as participants in a practical discourse' (Habermas 1992b, p. 66 ). By a 'practical discourse' Habermas is pointing to what he calls the ideal speech situation (ISS) (Habermas 1990, p. 86), a regulative ideal in which the result should depend only on the force of the better argument and not on any inequalities in knowledge, power, resources or rhetorical ability. The goal of this process is to try to generate a common will and not just an accommodation of interests. That is, the participants should become convinced that it is genuinely the best way for all of them to resolve their common differences.

Habermas developed his communicative and moral theories into a powerful model of the nature of democratic society within the post-national and multi-cultural age (Habermas 1996; 1999b; 2001). This has generated considerable debate within politics and legal circles (Dryzek 2002; O'Flynn 2006; 
Parkinson 2006). Deliberative democracy can be seen to weave together a whole variety of different forms of discourse and communication involving pragmatic choices and the balancing of interests; ethical debates about forms of community and the good life; moral discussion of a just society; and political and legal argumentation. This occurs not just in the traditional institutions of politics and the law, but increasingly in what Habermas refers to as the voluntary associations of civil society (Habermas 1996 ch. 8). The whole third sector of community and voluntary groups, pressure groups, NGOs, trade associations and lobbyists, underpinned by the explosion of communication technologies, now occupy the space between the everyday communicative lifeworld, the systems of economy and state.

There have been some applications of DE in business, both in terms of communication in organisations and at the level of the organisation as a political actor. For example, Palazzo and Scherer (Palazzo and Scherer 2006; Scherer and Palazzo 2007) argue that corporations need to become politicized in the sense that they need to become genuinely political agents within an increasing globalized, 'postnational' world - what they call 'political CSR'. They also argue, correctly we think, that in these days of fragmentation and de-centring we can no longer hope for a universal, a-historical set of moral standards for business and organizations:

"There is no "view from nowhere" from which a-historical and a-contextual ethical norms could be deduced. ... the question remains of how the legitimacy of corporate activities can be normatively accessed when no universal criteria of ethical behaviour are available in a post-modern and post-ethical world.' (Scherer and Palazzo 2011, p. 906)

We would argue that DE brings with it three advantages in comparison with traditional ethical theories. First, and in the light of the cultural pluralism mentioned above, it separates off ethical questions of the good life, which we can accept may be different for different people or groups, from the, perhaps small number, of moral issues that should be seen as universally valid. Quite how one draws this distinction is of course a debatable issue in its own right and Habermas talks of discourses of application (Habermas 1993a) which are necessary to decide on the applicability of particular norms. Second, the emphasis on universalisation - the inclusion of all those affected - pushes us to consider and involve as wide a range of stakeholders in decision-making as possible. This links in to practical methodologies within critical systems thinking that stress the importance of boundary decisions such as Churchman's ethics of systems design (Churchman 1979), Ulrich's critical systems heuristics (Ulrich 1994), Midgley's boundary critique (Midgley 2000), and Mingers' critical pluralism (Mingers 1997). Third, DE's focus on the actual involvement of stakeholders in practical discourses is a potentially valuable way of getting real resolution and commitment to finding ways to move forward in complex and contested situations. It links into soft approaches such as soft systems methodology (SSM) (Checkland and Scholes 1990) and cognitive mapping (Eden and Ackermann 2001) whose 
purpose is structuring complex problems through exploration and debate (Rosenhead and Mingers 2001).

There are also, of course, difficulties and criticisms of DE. The primary one is clearly that of impractical idealisation. The exacting demands of the ideal speech situation are unlikely to ever be met in practice, and the call for all those affected by a norm or plan to be involved in agreeing it is also unrealistic, particularly within the context of business (Mingers and Walsham 2010). Some suggest (Scherer and Palazzo 2011) that deliberative democracy is a more realistic development of the original idealism of DE although Edward and Willmot (2013) criticise this on two levels. First, they criticise what they see as Scherer and Palazzo's appropriation of the true spirit of discourse ethics and then they highlight limitations in DE itself. Scherer and Palazzo aim to use DE and particularly deliberative democracy to shore up the faltering legitimacy of corporations by effectively turning them into political actors who participate in the wider deliberative process. This is seen as a pragmatic move away from the philosophical grounding of DE in processes of equal and open discourse towards a political "fix" for corporations. And at the same time it takes attention away from Habermas's argument that deliberative democracy is justifiable to the extent that it helps to bring about a fairer society through a greater realisation of the principles of the "ideal speech situation" and the discourse principle. With regard to DE itself, they raise a deep philosophical point in questioning whether there is in fact some underlying positive foundation for critique or whether we need to begin by acknowledging that there is in fact no such point and we must begin only with absence, negativity and difference as Adorno (1973) would argue? They propose the work of Laclau and Mouffe (2001) radical democratisation - as a nonfoundational approach based in difference and relativity. This is not the place to debate such a deep issue but I would point out that Habermas himself recognises the importance of difference, saying:

‘... The equal respect for everyone else demanded by a moral universalism sensitive to difference thus takes the form of a nonleveling and nonappropriating inclusion of the other in his otherness.'(Habermas 1999a, p. 40)

Also, as we have seen, critical realism makes absence and negativity one of its founding moments and therefore may be able to address some of the concerns of Laclau and Mouffe. Even Edward and Willmot conclude that deliberative democracy may be a practical way forward (p. 571).

\subsection{Towards critical pluralism}

To summarise this section on business schools becoming critical and committed, we would suggest that critical realism and discourse ethics, although apparently in conflict, actually can be complements to each other (Mingers 2009). For (critical) realists, Habermas is not enough of a realist - he does not seem to accept the reality of social structures and mechanisms that constrain and oppress people in 
ways that go beyond moral debate and require emancipatory social science to critique existing moralities and inform discourse. And yet, in this overly complex world social science is hard pressed to explain and understand what is happening, let alone come up with robust and equitable alternatives. So does not CR depend, in the final analysis, on the agreements and commitments of participants, whether they are experts, politicians or ordinary citizens, and thus depend on discourse?

This leads to an approach that we might call critical pluralist - recognising that all action is ultimately committed to particular ends or interests and that this must be made open and explicit and the subject of unfettered debate; whilst at the same time accepting that complex, wicked problems require a plurality of disciplines and methodologies, and potentially involve a plurality of legitimate (and perhaps illegitimate) viewpoints and perspectives. This approach is pluralist in a variety of ways ontologically, in accepting the existence of a variety of causally-efficacious systems and structures, both tangible and intangible; epistemologically, in seeing the need for a variety of different research and intervention methods being combined together; and ethically in accepting that there will inevitably be a plurality of viewpoints which must be explored and debated rather than closed off and suppressed.

Dealing with complex real-world problems will always involve a challenge to or questioning of the status quo for it is, by definition, the status quo that needs changing. Such questioning may involve four aspects or types of critiques (Mingers 2000b):

- Critique of rhetoric - challenging the arguments, propositions, assumptions and information currently available.

- Critique of tradition - challenging the taken-for-granted ways of doing things.

- Critique of authority - challenging the idea of a single dominant or privileged position.

- Critique of objectivity - challenging the presumption that knowledge can be objective and interest-free.

\section{ACTION - WILL ANYTHING CHANGE?}

It is all very well to propose these rather abstract and philosophical ideas and suggest, in a counterfactual way, that if the world were like this all would be well. But is there actually any prospect of significant change taking place when the structures involved, both internal and environmental, are so mutually reinforcing and deeply sedimented? I hope to show in this section that there are indeed signs of hope - the "green shoots of recovery".

I shall first consider moves internal to the business school world and then the perhaps more significant ones in the environment. Whilst the two principal paradigms of positivism and constructivism still maintain their hegemony within management research, there are clear signs that the inadequacies of 
the two individually, and even more so the incommensurability thesis that forces researchers to inhabit one or the other, are taking their toll. Critical realism, to the extent that it can be seen as a way of overcoming this dichotomy, is becoming ever more popular. Figure 3 shows the number of papers and corresponding number of citations resulting from a search of Web of Science under "critical realism or critical realist" within the business and management field (24/5/2014). The strong upward path, particularly terms of citations, it unmistakeable. Perusing the titles, they are not only philosophical/methodological contributions but include many empirical/case study examples as well. There have also been special issues of top journals, e.g., Organization Studies (2011), MIS Quarterly (2013) and Industrial and Marketing Management (2013).

\section{Figure 3 about here}

Allied to this, and stemming from the same frustrations, is a rise in the amount of research that is multi- or mixed-method. Again, many researchers recognize that being straight-jacketed into either a quantitative- or qualitative-only research design does not enable them to address the richness of the organizational world. One of the first books to be devoted to mixed method research was Tashakkori and Teddlie (1998) published in 1998, and Mingers and Gill (1997) published a book on multimethodology in OR/MS in 1997. Figure 4 shows the results of WoS searches for "mixed methods" or "multimethodology" across the social sciences. Again, the results speak for themselves from the late 1990s onwards activity has increased exponentially. This is reflected in research methods textbooks which used to be split into qual. and quant.; then had a small mixed-methods section; but now may be devoted wholly to mixed-methods - e.g., (Creswell and Clark 2007). Bryman (2006) has edited a massive four volume work devoted solely to mixed-methods. There are also new journals appearing, e.g. the Journal of Mixed Methods Research and the International Journal of Multiple Research Approaches both started in 2007.

\section{Figure 4 about here}

We should also consider the extent to which critical management approaches are making any headway. As we saw above, there are debates within CMS as to the extent to which it should even try to become practically engaged rather than remaining as an outside critique, but we would follow Delbridge (2014) in arguing that CMS can and should become involved "to make individual citizens' 'private troubles' public issues for attention, and address societal problems in ways that sustain society's moral sentiments and sympathetic imagination for the betterment of humankind" (Delbridge 2014, p. 111). At WBS, while I was there, a new core module compulsory for all third year undergraduates called Critical Issues in Management was introduced (Mingers 2000b). The title played on two senses of "critical" - being important and being questioning. It tried to encompass many of the themes of this paper being based around case studies rather than lectures; requiring extensive student participation; recognizing rather than supressing ethical issues; and being strongly 
interdisciplinary. It was hard teaching it not least because it challenged many of the students' preconceptions about education (e.g., that there is no right answer), especially those coming from technical backgrounds such as accounting. It has been taken up at other institutions, e.g., Birmingham ${ }^{5}$. We can also point to the successful development of a new management school at Leicester University which set out to be critically oriented.

The problems that we face today are complex, multidisciplinary and resistant to easy, technocratic solutions. They will require multidisciplinary teams, transdisciplinary thinking, a willingness to develop perhaps unorthodox and radical ideas, and a continual commitment to put the interests of ordinary citizens and society as a whole above those of corporations, political parties or even nation states. This is very much a role that can be played by critical researchers if they are willing to "get their hands dirty" engaging with real world problems rather than self-centred critique. It is also an arena in which operational research and systems thinking have much to offer through their combination of powerful analytical tools that can make us of the big data now available to us, and problem structuring methodologies to sharpen our focus in messy complex situations. It is worth mentioning the work of John Brewer (2013) and his development of a "new public social science" for it has many resonances with both critical realism and critical management studies that are well brought out by Delbridge (2014).

We now move to some of the factors that are external to business schools and effectively out of their control. The first, especially in the UK, is the Research Excellence Framework (REF, used to be RAE). As we saw above, in the past this led to an over-concentration on theoretical papers in $4 *$ journals, but the latest REF (2014) brought in external impact as one of its dimensions, counting $20 \%$ towards the total score (publications count for 65\%). By external impact is meant specifically impact on the external world, not academic impact as in citations. This caused a considerable degree of panic within the schools as they had not focussed on this in the past, and found it difficult to evidence any impacts they had had. This move is likely to generate a major shift in behaviour in the future, not least because impact will be worth $25 \%$ in the next, 2020 , REF. Schools will now have to value and promote research that has external impact even it is not publishable in $4^{*}$ journals. Given the importance of the REF rankings for business schools, in terms of prestige even more than direct government funding, this could be the necessary lever to start the external engagement ball rolling. It is not only the UK's REF that is emphasising impact, but also the AACSB with its impact report, and research appraisals in Australia and New Zealand. This in turn is already leading to greater engagement with businesses and external projects - schools are becoming desperate to establish partnerships that give the opportunity for impact as well as other purposes particularly student employability.

\footnotetext{
${ }^{5}$ Personal communication from Prof. Paul Edwards
} 
The major sticking point remains the top journals with their theoretical biases ${ }^{6}$. It is vital that they recognise in some way the importance of empirical, case based research so that it can be seen as being of equal (if not greater) value than pure theory. The way forward can perhaps be seen in those few top journals that are practically oriented such as Harvard Business Review.

We turn next to the universities and their VCs. There is little evidence here, but my belief is that VCs are primarily concerned that business schools are successful academically in terms of rankings, and financially in terms of continuing large surpluses. They would not be against a move towards a more practical, practice-based orientation so long as it did not lead to a loss of position or money. But I do not detect any particular desire to move in that direction, other than that generated by the impact agenda in the REF, brought about by government.

\section{CONCLUSIONS}

In the introduction, we identified a range of problems that are seen to be besetting business schools at this time - lack of engagement with external organisations, irrelevance of research, inappropriate teaching curricula, little concern for pressing social issues and questionable ethical commitments. In the second section we analysed a range of historical and structural mechanisms which generated this situation initially, and now sustain it, making change difficult to bring about. The main purpose of the paper, however, it to propose a combination of approaches that mutually reinforce one another and that, taken together, could break into the current vicious cycle and perhaps begin to turn it round towards more practical, relevant and engaged activity. The philosophical approach of critical realism forms the scaffolding for this proposal.

- CR works as an underpinning philosophy that allows us to accept the strengths of both empiricism and constructionism without having to accept their limitations in terms of realworld problem solving. It asserts the existence of a causally efficacious real world while accepting the inevitably limited nature of our access to that world. It thereby directs our attention to go beyond simply describing what we experience, whether in terms of empirical observations or personal values and beliefs, towards trying to explain the causality behind these experiences and thus towards being able to change them. Where desired

- Critical realism naturally leads into a holistic and systemic worldview which itself necessitates transdisciplinarity - an overcoming of the current disciplinary silos. This is necessary because the serious problems that we face are inevitably complex, inter-woven and multi-dimensional and resist reductionist or partial approaches.

\footnotetext{
${ }^{6}$ As a personal example, I had a paper analysing the 2008 RAE results rejected by both the British Journal of Management, and the Journal of Management Studies on the grounds that they did not consider purely empirical papers.
} 
- The pluralist character of critical realism and the need for holism and transdisciplinarity in turn mean that we need mixed-method research to employ together a range of research methodologies, empirical, interpretive and oriented towards practical action (action research).

- Finally, critical realism destroys the illusion that research can be value-free research and that we can turn a blind eye to the effects of our research activities, or indeed to our lack of activity. Instead, it argues that social science is committed towards trying to achieve a better society for all.

Nor is all this an idle pipe-dream - there are real signs that we have reached a cusp in which both internal and external pressures for change could lead to business schools becoming meaningfully engaged in helping society face its real problems.

\section{REFERENCES}

AACSB, 2008. Final Report of the AACSB International Impact of Research Task Force, AACSB, Florida.

Ackerman, F., 2012. Problem structuring methods 'in the Dock': Arguing the case for Soft OR. European Journal of Operational Research 219, 652-658.

Ackoff, R., 1979a. The future of operational research is past. Journal of the Operational Research Society 30, 93-104.

Ackoff, R., 1979b. Resurrecting the future of operational research. Journal of the Operational Research Society 30, 189-199.

Adler, N., and Harzing, A.-W., 2009. When knowledge wins: Transcending the sense and nonsense of academic rankings. Academy of Management Learning and Education 8 (1), 72-95.

Adorno, T., 1973. Negative Dialectics, Seabury Press: New York.

Al-Amoudi, I., and Willmott, H., 2011. Where constructionism and critical realism converge: Interrogating the domain of epistemological relativism. Organization Studies 32 (1), 27-46.

Alvesson, M., 2008. The future of critical management studies. In: D. Barry and H. Hansen (eds.), The SAGE Handbook of New Approaches in Management and Organization. Sage, London 1330.

Alvesson, M., Bridgman, T., and Willmott, H., 2009a. Introduction. In: M. Alvesson, T. Bridgman and H. Willmott (eds.), The Oxford Handbook of Critical Management Studies. Oxford University Press, Oxford 1-28.

Alvesson, M., Bridgman, T., and Willmott, H. (eds.), 2009b The Oxford Handbook of Critical Management Studies. Oxford University Press, Oxford.

Alvesson, M., and Willmott, H. (eds.), 1992 Critical Management Studies. SAGE Publications, London.

Alvesson, M., and Willmott, H., 1996. Making Sense of Management: a Critical Introduction, Sage: London.

Antonacopoulou, E., 2010. Making the business school more 'critical': Reflexive critique based on phronesis as a foundation for impact. British Journal of Management 21, s6-s25.

Archer, M., 2000. Being Human: The Problem of Agency, Cambridge University Press: Cambridge.

Archer, M., 2003. Structure, Agency and the Internal Conversation, Cambridge University Press.: Cambridge.

Archer, M., 2007. Making Our Way Through the World: Human Reflexivity and Social Mobility, Cambridge University Press.: Cambridge.

Bateson, G., 1980. Mind and Nature: A Necessary Unity, Hampton Press

Bennett, P., 1985. On linking approaches to decision-aiding: issues and prospects. Journal of the Operational Research Society 36 ( 8), 659-670. 
Bennis, W., and O'Toole, J., 2005. How business schools lost their way. Harvard Business Review 83, 96-104.

Bhaskar, R., 1978. A Realist Theory of Science, Harvester: Hemel Hempstead.

Bhaskar, R., 1979. The Possibility of Naturalism, Harvester Press: Sussex.

Bhaskar, R., 1986. Scientific Realism and Human Emancipation, Verso: London.

Bhaskar, R., 1989. Reclaiming Reality, Verso: London.

Bhaskar, R., 1993. Dialectic: the Pulse of Freedom, Verso: London.

Bhaskar, R., 1994. Plato Etc, Verso: London.

Bhaskar, R., 2000. From East to West: Odyssey of a Soul, Routledge: London.

Bhaskar, R., 2002a. From Science to Emancipation: Alienation and the Actuality of Enlightenment, Sage: London.

Bhaskar, R., 2002b. Reflections on Meta-Reality: Transcendence, Emancipation and Everyday Life Routledge: London.

Bhaskar, R., 2010. Contexts of interdisciplinarity: Interdisciplinarity and climate change. In: R. Bhaskar, C. Frank, K. G. Høyer, P. Naess and J. Parker (eds.), Interdisciplinarity and Climate Change: Transforming Knowledge and Practice for Our Global Future. Routledge, London 124.

Bhaskar, R., Frank, C., Høyer, K. G., Naess, P., and Parker, J. (eds.), 2010 Interdisciplinarity and Climate Change: Transforming Knowledge and Practice for Our Global Future. Routledge, London.

Bhaskar, R., and Hartwig, M., 2010. The Formation of Critical Realism: A Personal Perspective Routledge: London.

Brewer, J., 2013. The Public Value of Social Science, Bloomsbury: London.

Brown, A., 2013. Critical realism in social research: approach with caution. Work, Employment \& Society forthcoming.

Bryman, A. (ed.) 2006 Mixed Methods. Sage, London.

Burningham, K., and Cooper, G., 1999. Being constructive: Social constructionism and the environment. Sociology 33 (2), 297-316.

Burrell, G., and Morgan, G., 1979. Sociological Paradigms and Organisational Analysis, Heinemann: London.

Capra, F., 1997. The Web of Life: a New Synthesis of Mind and Matter, Flamingo: London.

Checkland, P., 1980. The systems movement and the "failure" of management science. Cybernetics and Systems 11, 317-324.

Checkland, P., 1981. Systems Thinking, Systems Practice, Wiley: Chichester.

Checkland, P., 1983. OR and the systems movement - mappings and conflicts. Journal of the Operational Research Society 34 (8), 661-675.

Checkland, P., 1985. From optimizing to learning: a development of systems thinking for the 1990s. Journal of the Operational Research Society 36 (9), 757-768.

Checkland, P., and Scholes, J., 1990. Soft Systems Methodology in Action, Wiley: Chichester.

Chia, R., and Holt, R., 2008. The nature of knowledge in business schools. Academy of Management Learning \& Education 7 (4), 471-486.

Churchman, C. W., 1979. The Systems Approach and its Enemies, Basic Books: New York.

Churchman, C. W., 1994. Management science: Science of managing and managing of science. Interfaces 24 (4), 99-110.

Churchman, C. W., and Schainblatt, A., 1965. The researcher and the manager: a dialectic of implementation. Management Science 11 (4), B69-B87.

Contu, A., 2009. Critical management education. In: M. Alvesson, T. Bridgman and H. Willmott (eds.), The Oxford Handbook of Critical Management Studies. Oxford University Press, Oxford 536-550.

Contu, A., and Willmott, H., 2005. You spin me round: the realist turn in organization and management studies. Journal Management Studies 42 (8), 1645-1662.

Creswell, J., 2009. Research Design: Quantitative, Qualitative and Mixed Method Approaches, Sage: Los Angeles.

Creswell, J., and Clark, V., 2007. Designing and Conducting Mixed Methods Research, Sage: Thousand Oaks. 
Delbridge, R., 2014. Promising futures: CMS, post-disciplinarity, and the new public social science. Journal of Management Studies 51 (1), 95-117.

Delbridge, R., and Edwards, T., 2013. Inhabiting Institutions: Critical Realist Refinements to Understanding Institutional Complexity and Change. Organization Studies 34 (7), 927-947.

DeTombe, D., 2002. Complex societal problems in operational research. Eur. J. Operational Research 140, 232-240.

Dobson, P., 2001. The philosophy of critical realism - an opportunity for information systems research. Information Systems Frontiers 3 (2), 199-210.

Drake, D., Lovejoy, A., Rogers, A., Santayana, G., Sellars, R., and Strong, C., 1920. Essays in Critical Realism: A Co-Operative Study of the Problem of Knowledge, macmillan: London.

Dryzek, J., 2002. Deliberative Democracy and Beyond: Liberals, Critics, Contestations, Oxford University Press: Oxford.

Durand, R., and McGuire, J., 2005. Legitimating agencies in the face of selection: The case of AACSB. Organization Studies 26 (2), 165-196.

Durand, R., and Vaara, E., 2009. Causation, counterfactuals, and competitive advantage. Strategic Management Journal 30, 1245-1264.

Durand, T., and Dameron, S., 2011. Where have all the business schools gone? British Journal of Management 22, 559-563.

Dyson, R. G., 2004. Strategic development and SWOT analysis at the University of Warwick. European Journal of Operational Research 152, 631-640.

Easton, G., 2002. Marketing - A critical realist approach. Journal of Business Research 55 (2), 103109.

Easton, G., 2010. Critical realism in case study research. Industrial Marketing Management 39 (1), $118-128$.

Eden, C., and Ackermann, F., 2001. SODA - the principles. In: J. Rosenhead and J. Mingers (eds.), Rational Analysis for a Problematic World Revisited: Problem Structuring Methods for Complexity, Uncertainty and Conflict. Wiley, Chichester 21-42.

Eden, C., Jones, S., and Sims, D., 1983. Messing About in Problems, Pergamom: Oxford.

Edward, P., and Willmott, H., 2013. Discourse and normative business ethics. In: C. Luetge (ed.), Handbook of the Philosophical Foundations of Business Ethics. Springer, New York 549-580.

Espinosa, A., Hamden, R., and Walker, J., 2008. A complexity approach to sustainability - Stafford Beer revisited. European Journal of Operational Research 187 (2), 636-651.

ESRC, 1994. Building Partnerships: Enhancing the Quality of Management Research, ESRC, Swindon.

Fairclough, N., 2005. Peripheral Vision: Discourse Analysis in Organization Studies: The Case for Critical Realism. Organization Studies 26 (6), 915-939.

Fincham, R., and Clark, T., 2009. Introduction: Can We Bridge the Rigour-Relevance Gap? Journal of Management Studies 46 (3), 510-515.

Fleetwood, S., 2013. Critical realism and systematic dialectics: a reply to Andrew Brown. Work, Employment \& Society.

Fleetwood, S., and Ackroyd, S. (eds.), 2004 Critical Realist Applications in Organisation and Management Studies. Routledge, London.

Ford, J., harding, N., and Learmouth, M., 2010. Who is it that would make business schools more critical? Critical reflections on critical management studies. British Journal of Management 21, s71-s81.

Forrester, J., 1968. Principles of Systems, MIT Press: Cambridge.

Fournier, V., and Grey, C., 2000. At the Critical Moment: Conditions and Prospects for Critical Management Studies. Human Relations 53 (1), 7-32.

Friedman, M., 1962. Capitalism and Freedom, University of Chicago Press: Chicago.

Ghoshal, S., 2005. Bad management theories are destroying good management practices. Academy of Management Learning and Education 4 (1), 75-91.

Gibbons, M., Limoges, L., Nowotny, H., Schwartman, S., Scott, P., and Trow, M., 1994. The New Production of Knowledge. The Dynamics of Science and Research in Contemporary Societies, Sage: London. 
Gordon, R., and Howell, J., 1959. Higher Education for Business, Columbia University Press New York.

Gosh, S., Troutt, M., Thornton, J., and Offodile, O., 2010. A empirical method for assessing the research relevance gap. European Journal of Operational Research 201, 942-948.

Greene, J., 2007. Mixed Methods in Social Enquiry, Jossey Bass: San Francisco.

Grey, C., 2001. Re-imagining relevance: a response to Starkey and Madan. British Journal of Management 12, s27-s32.

Grey, C., 2005. A Very Short, Fairly Interesting and Relatively Cheap Book about Organisations, Sage: London.

Habermas, J., 1971. Towards a Rational Society, Heinemann: London.

Habermas, J., 1990. Moral Consciousness and Communicative Action, Polity Press: Cambridge.

Habermas, J., 1992a. Discourse ethics, law and Sittlichkeit. In: P. Dews (ed.), Autonomy and Solidarity : Interviews with Jürgen Habermas. Verso, London 245-271.

Habermas, J., 1992b. Discourse ethics: Notes on a programme of philosophical justification. In: J. Habermas (ed.), Moral Consciousness and Communicative Action. Polity Press, Cambridge 43115.

Habermas, J., 1993a. Justification and Application, Polity Press: Cambridge.

Habermas, J., 1993b. On the pragmatic, the ethical, and the moral employments of practical reason. In: J. Habermas (ed.), Justification and Application. Polity Press, Cambridge 1-17.

Habermas, J., 1996. Between Facts and Norms, Polity Press: Cambridge.

Habermas, J., 1999a. A genealogical analysis of the cognitive content of morality. The Inclusion of the Other. Polity Press, Cambridge 3-48.

Habermas, J., 1999b. The Inclusion of the Other, Polity Press: Cambridge.

Habermas, J., 2001. The Postnational Constellation: Political Essays, Polity Press: Cambridge.

Hall, A. D., 1962. A methodology for systems engineering, Van Nostrand Reinhold: N.Y.

Hartwig, M., 2007. Dictionary of Critical Realism, Routledge: Abingdon.

Hector, D., Christensen, C., and Petrie, J., 2009. A problem-structuring method for complex societal decisions: Its philosophical and psychological dimensions. European Journal of Operational Research 193, 693-708.

HEFCE, 2007. Research Excellence Framework: Consultation on the assessment and funding of higher education research post-2008, HEFCE.

HEFCE, 2009. Research Excellence Framework: invitation to participate in a pilot exercise to assess impact

Heims, S., 1993. Constructing a Social Science for Postwar America: The Cybernetics Group 19461953, MIT Press: Massachusetts.

Hodgkinson, G. P., and Rousseau, D. M., 2009. Bridging the Rigour-Relevance Gap in Management Research: It's Already Happening! Journal of Management Studies 46 (3), 534-546.

Hodgkinson, G. P., and Starkey, K., 2011. Not simply returning to the same answer over and over again: reframing relevance. British Journal of Management 22 (3), 355-369.

Hodgkinson, G. P., and Starkey, K., 2012. Extending the Foundations and Reach of Design Science: Further Reflections on the Role of Critical Realism. British Journal of Management 23 (4), 605610.

Hume, D., 1967 (orig. 1750). Enquiries Concerning Human Understanding and the Principles of Morals, Clarendon Press: Oxford.

Inman, P., 2013. Economics lecturers accused of clinging to pre-crash fallacies. Guardian, Guardian Newspapers, London.

Jackson, M., 1990. Beyond a system of systems methodologies. Journal of the Operational Research Society 41 (8), 657-668.

Jackson, M., 1991. The Origins and Nature of Critical Systems Thinking. Systems Practice 4 (2), 131149.

Jackson, M., 1993. Social Theory and Operational Research Practice. Journal of the Operational Research Society 44 (6), 563-577.

Jackson, M., 2001. Critical systems thinking and practice. European Journal of Operational Research $128,233-244$.

Jackson, M., 2003. Systems Thinking: Creative Holism for Managers, Wiley: Chichester. 
Khurana, R., 2007. From Higher Aims to Hired Hands: The Social Transformation of American Business Schools and the Unfulfilled Promise of Management as a Profession, Princeton University Press: Princeton.

Kieser, A., and Leiner, L., 2009. Why the Rigour-Relevance Gap in Management Research Is Unbridgeable. Journal of Management Studies 46 (3), 516-533.

Kilduff, M., and Kelemen, M., 2001. The Consolations of Organization Theory. British Journal of Management 12, S55-S59.

Kilduff, M., Mehra, A., and Dunn, M., 2011. From blue sky research to problem solving: A philosophy of science theroy of new knowledge production. Academy of Management Review 36 (2), 297-317.

Laclau, E., and Mouffe, C., 2001. Hegemony and Socialist Strategy: Towards a Radical Democratic Politics, Verso: London.

Leca, B., and Naccache, P., 2006. A critical realist approach to institutional entrepreneurship. Organization 13, 627-651.

Locke, E., and Spender, J., 2011. Confronting Managerialism, Zed Books: London.

Midgley, G., 2000. Systemic Intervention: Philosophy, Methodology, and Practice, Kluwer.Plenum: New York.

Mingers, J., 1980. Towards an appropriate social theory for applied systems thinking: critical theory and soft systems methodology. Journal Applied Systems Analysis 7 (April), 41-50.

Mingers, J., 1984. Subjectivism and soft systems methodology - a critique. Journal Applied Systems Analysis 11, 85-103.

Mingers, J., 1992. Recent developments in critical management science. Journal of the Operational Research Society 43 ( 1), 1-10.

Mingers, J., 1997. Towards critical pluralism. In: J. Mingers and A. Gill (eds.), Multimethodology: Theory and Practice of Combining Management Science Methodologies. Wiley, Chichester 407440.

Mingers, J., 2000a. The contribution of critical realism as an underpinning philosophy for OR/MS and systems. Journal of the Operational Research Society 51 (11), 1256-1270.

Mingers, J., 2000b. What is it to be critical? Teaching a critical approach to management undergraduates. Management Learning 31 (2), 219-237.

Mingers, J., 2004a. Can social systems be autopoietic? Bhaskar's and Giddens' social theories. Journal for the Theory of Social Behaviour 34 (4), 403-426.

Mingers, J., 2004b. Re-establishing the real: critical realism and information systems research. In: J. Mingers and L. Willcocks (eds.), Social Theory and Philosophy for Information Systems. Wiley, London 372-406.

Mingers, J., 2004c. Real-izing information systems: critical realism as an underpinning philosophy for information systems. Information and Organization 14 (2), 87-103.

Mingers, J., 2006a. A critique of statistical modelling in management science from a critical realist perspective: its role within multimethodology. Journal Operational Research Society 55 (2), 202-219.

Mingers, J., 2006b. Realising Systems Thinking: Knowledge and Action in Management Science, Springer: New York.

Mingers, J., 2009. Discourse ethics and critical realist ethics: An evaluation in the context of business. Journal of Critical Realism 8 (2), 172-200.

Mingers, J., 2011a. The contribution of systemic thought to critical realism. Journal of Critical Realism 10 (3), 303-330.

Mingers, J., 2011b. Ethics and OR: Operationalizing discourse ethics. European Journal of Operational Research 210 (1), 114-124.

Mingers, J., 2011c. Soft OR comes of age - but not everywhere! Omega 39 (6), 729-741.

Mingers, J., 2014. Systems Thinking, Critical Realism and Philosophy: A Confluence of Ideas, Routledge: London.

Mingers, J., and Brocklesby, J., 1997. Multimethodology: towards a framework for mixing methodologies. Omega 25 (5), 489-509.

Mingers, J., and Gill, A. (eds.), 1997 Multimethodology: Theory and Practice of Combining Management Science Methodologies. Wiley, Chichester. 
Mingers, J., Mutch, A., and Willcocks, L., 2013. Critical Realism in Information Systems Research MIS Quarterly 37 (3), 795-802.

Mingers, J., and Rosenhead, J., 2004. Problem structuring methods in action. European Journal Operational Research 152 (3), 530-554.

Mingers, J., and Walsham, G., 2010. Towards ethical information systems: The contribution of discourse ethics. MIS Quarterly 34 (4), 833-854.

Mingers, J., Watson, K., and Scaparra, M. P., 2012. Estimating Business and Management journal quality from the 2008 Research Assessment Exercise in the UK. Information Processing and Management 48 (6), 1078-1093.

Mingers, J., and White, L., 2010. A review of the recent contribution of systems thinking to operational research and management science. European Journal of Operational Research 207 (3), 1147-1161.

Mingers, J., and Willmott, H., 2013. Taylorizing business school research: On the "one best way" performative effects of journal ranking lists. Human Relations 66 (8), 1051-1073.

Mir, R., and Watson, A., 2001. Critical realism and constructivism in strategy research: Toward a synthesis. Strategic Management Journal 22 (12), 1169-1173.

Modell, S., 2009. In defence of triangulation: A critical realist approach to mixed methods research in management accounting. Management Accounting Research 20 (3), 208-221.

Mutch, A., 2005. Critical realism, agency and discourse: moving the debate forward. Organization 12 (5), 781-786.

Newton, T., Deetz, S., and Reed, M., 2011. Responses to social constructionism and critical realism in organization studies. Organization Studies 32 (1), 7-26.

Niiniluoto, I., 2002. Critical Scientific Realism, Oxford University Press: Oxford.

O'Flynn, I., 2006. Deliberative Democracy and Divided Societies, Edinburgh University Press: Edinburgh

Ormerod, R. J., and Ulrich, W., 2013. Operational research and ethics: A literature review. European Journal of Operational Research 228 (2), 291-307.

Palazzo, G., and Scherer, A., 2006. Corporate legitimacy as deliberation: A communicative framework. Journal of Business Ethics 66, 71-88.

Parker, M., 2014. University, Ltd: Changing a business school. Organization 21 (2), 281-292.

Parkinson, J., 2006. Deliberating in the Real World: Problems of Legitimacy in Deliberative Democracy, Oxford University Press, Oxford.

Pettigrew, A., 1997. The double hurdles for management research. In: T. Clarke (ed.), Advancement in Organizational Behaviour: Essays in Honour of D.S. Pugh. Dartmouth Press, London 277296.

Pettigrew, A., 2011. Scholarship with impact. British Journal of Management 22, 347-354.

Pfeffer, J., and Fong, C. T., 2002. The End of Business Schools? Less Success Than Meets the Eye. Academy of Management Learning \& Education 1 (1), 78-95.

Pfeffer, J., and Fong, C. T., 2004. The Business School 'Business': Some Lessons from the US Experience*. Journal of Management Studies 41 (8), 1501-1520.

Plano Clark, V., and Cresswell, J., 2007. The Mixed Methods Reader, Sage: Thousand Oaks.

Plowright, D., 2011. Using Mixed Methods: Frameworks for an Integrated Methodology, Sage: Thousand Island.

Reed, M., 1997. In praise of duality and dualism: rethinking agency and structure in organizational analysis. Organization Studies 18 (1), 21-42.

Reed, M., 2005. Reflections on the "realist turn" in organization and management studies. Journal Management Studies 42 (8), 1621-1644.

Reed, M., 2009a. Critical realism in critical management studies. In: M. Alvesson, T. Bridgman and H. Willmott (eds.), The Oxford Handbook of Critical Management Studies. Oxford University Press, Oxford 52-75.

Reed, M., 2009b. The theory/practice gap: A problem for research in business schools? Journal of Management Development 28 (8), 685-693.

Rittel, H., and Webber, M., 1973. Dilemmas in a general theory of planning. Policy Sciences 4, 155169.

Rosenau, P., 1992. Post-Modernism and the Social Sciences, Princeton University Press: Princeton. 
Rosenhead, J., and Mingers, J. (eds.), 2001 Rational Analysis for a Problematic World Revisited. Wiley, Chichester.

Scherer, A., and Palazzo, G., 2007. Towards a political conception of corporate responsibility: Business and society seen from a Habermasian perspective. Academy of Management Review 32 (4), 1096-1120.

Scherer, A., and Palazzo, G., 2011. The new political role of business in a globalized world: A review of a new perspective on CSR and its implications for firm, governance and democracy. Journal of Management Studies 48 (4), 899-931.

Sellars, R., 1916. Critical Realism: A Study of the Nature and Conditions of Knowledge, Rand McNally: New York.

Sherden, W., 1998. The Fortune Sellers: The Big Business of Buying and Selling Predictions, Wiley: New York.

Silver, N., 2012. The Signal and the Noise: The Art and Science of Prediction, Penguin: London.

Sodhi, M., and Tang, C., 2008. The OR/MS ecosystem: Strengths, weaknesses, opportunities, and threats. Operations Research 56 (2), 267-277.

Spicer, A., Alvesson, M., and Kärreman, D., 2009. Critical performativity: The unfinished business of critical management studies. Human Relations 62 (4), 537-560.

Starkey, K., and Madan, P., 2001. Bridging the relevance gap: aligning stakeholders in the future of management research. British Journal of Management 12, s3-s26.

Starkey, K., and Tempest, S., 2009. From crisis to purpose. Journal of Management Development 28 (8), 700-710.

Starkey, K., and Tiratsoo, N., 2007. The Business School and the Bottom Line, Cambridge University Press: Cambridge.

Sterman, J., 2000. Business Dynamics: Systems Thinking and Modelling for a Complex World, McGraw-Hill: New York.

Stock, P., and Burton, R., 2011. Defining terms for integrated (multi-inter-trans-disciplinary) sustainability research. Sustainability 3, 1090-1113.

Syed, J., Mingers, J., and Murray, P., 2009. Beyond rigour and relevance: A critical realist approach to business education. Management Learning 41 (1), 71-85.

Tashakkori, A., and Teddlie, C., 1998. Mixed Methodology: Combining Qualitative and Quantitative Approaches, SAGE Publications: London.

Tashakkori, A., and Teddlie, C., 2003. Handbook of Mixed Methods in Social and Behavioural Research, Sage: Thousand Oaks, CA.

Thomas, H., 2011. Business school futures: evaluation and perspectives. Journal of Management Development 30 (5), 444-450.

Thomas, H., and Cornuel, E., 2012. Business schools in transition? Issues of impact, legitimacy, capabilities and re-invention. Journal of Management Development 31 (4), 329-335.

Thomas, H., Thomas, L., and Wilson, A.-. 2013. The unfulfilled promise of management education (ME): the role, value and purposes of ME. Journal of Management Development 32 (5), 460476.

Thomas, H., and Wilson, D., 2012. The legitimacy of the business of business schools: what's the future? Journal of Management Development 31 (4), 368-376.

Thompson, E., 1970. Warwick University Ltd: Industry, Management and the Universities, Penguin: Harmondsworth.

Thompson, P., 2004. Brands, boundaries and bandwagons: A critical reflection on critical management studies. In: S. Fleetwood and S. Ackroyd (eds.), Critical Realist Applications in Organisation and Management Studies. Routledge, London 54-70.

Thompson, P., and Harley, B., 2012. Beneath the Radar? A Critical Realist Analysis of 'The Knowledge Economy' and 'Shareholder Value' as Competing Discourses. Organization Studies 33 (10), 1363-1381.

Tourish, D., 2013. 'Evidence based management', or 'evidence oriented organizing'? A critical realist perspective. Organization 20 (2), 173-192.

Tranfield, D., and Starkey, K., 1998. The nature, social organization and promotion of management research: towards policy. British Journal of Management 9 (341-353). 
Tsang, E., and Kwan, K., 1999. Replication and theory development in organizational science: a critical realist perspective. Academy of Management Review 24 (4), 759-780.

Tsang, E. W. K., 2013. Case studies and generalization in information systems research: A critical realist perspective. The Journal of Strategic Information Systems forthcoming.

Ulrich, W., 1994. Critical Heuristics of Social Planning: a New Approach to Practical Philosophy, Wiley: Chichester.

Ulrich, W., 2007. Philosophy for professionals: Towards critical pragmatism. Journal of the Operational Research Society 58, 1109-1117.

van de Ven, A. H., and Johnson, B., 2006. Knowledge for theory and practice. Academy of Management Review 31 (4), 802-21.

Venkatesh, V., Brown, S., and Bala, H., 2013. Bridging the qualitative-quantitative divide: Guidelines for conducting mixed methods in information systems. MIS Quarterly 37 (1), 21-54.

Vincent, S., 2008. A transmutation theory of inter-organizational exchange relations and networks: Applying critical realism to analysis of collective agency. Human Relations 61 (6), 875-899.

von Bertalanffy, L., 1971. General Systems Theory, Penguin: London.

von Uexkull, J., 1909. Umwelt und Innenwelt der Tiere, Springer: Berlin.

Weiskopf, R., and Willmott, H., 2013. Ethics as Critical Practice: The "Pentagon Papers", Deciding Responsibly, Truth-telling, and the Unsettling of Organizational Morality. Organization Studies 34 (4), 469-493.

Wiek, A., and Walter, A., 2009. A transdisciplinary approach for formalized integrated planning and decision-making in complex systems. European Journal of Operational Research 197, 360-370.

Willmott, H., 2005. Theorising contemporary control: some post-structuralist responses to some critical realist questions. Organization 12 (5), 747-780.

Willmott, H., 2011. Book Review: Making sense of the financial meltdown - an extended review of The Spectre at the Feast: Capitalist Crisis and the Politics of Recession. Organization 18 (2), 239-260.

Willmott, H., 2012. Reframing relevance as 'social usefulness': A comment on Hodgkinson and Starkey's 'Not simply returning to the same answer over and over again'. British Journal of Management 23 (4), 598-604.

Wilson, D., and McKiernan, P., 2011. Global mimicry: Putting strategic choice back on the business school agenda. British Journal of Management 22 (3), 457-469.

Wilson, D., and Thomas, H., 2012. The legitimacy of the business of business schools: What's the future. Journal of Management Development 31 (4), 368-376.

Wood, S., and Kelly, J., 1978. Towards a critical management science. Journal Management Studies $15,1-24$.

Woodger, J., 1929. Biological Principles: a Critical Study, Keegan, Paul and Co.: London.

Wray-Bliss, E., 2009. Ethics: Critique, ambivalence and infinite responsibilities (unmet). In: M. Alvesson, T. Bridgman and H. Willmott (eds.), The Oxford Handbook of Critical Management Studies. Oxford University Press, Oxford 267-285.

Wynn, D., and Williams, C. K., 2012. Principles for conducting critical realist case study research in information systems. MIS Quarterly 36 (3), 787-810. 


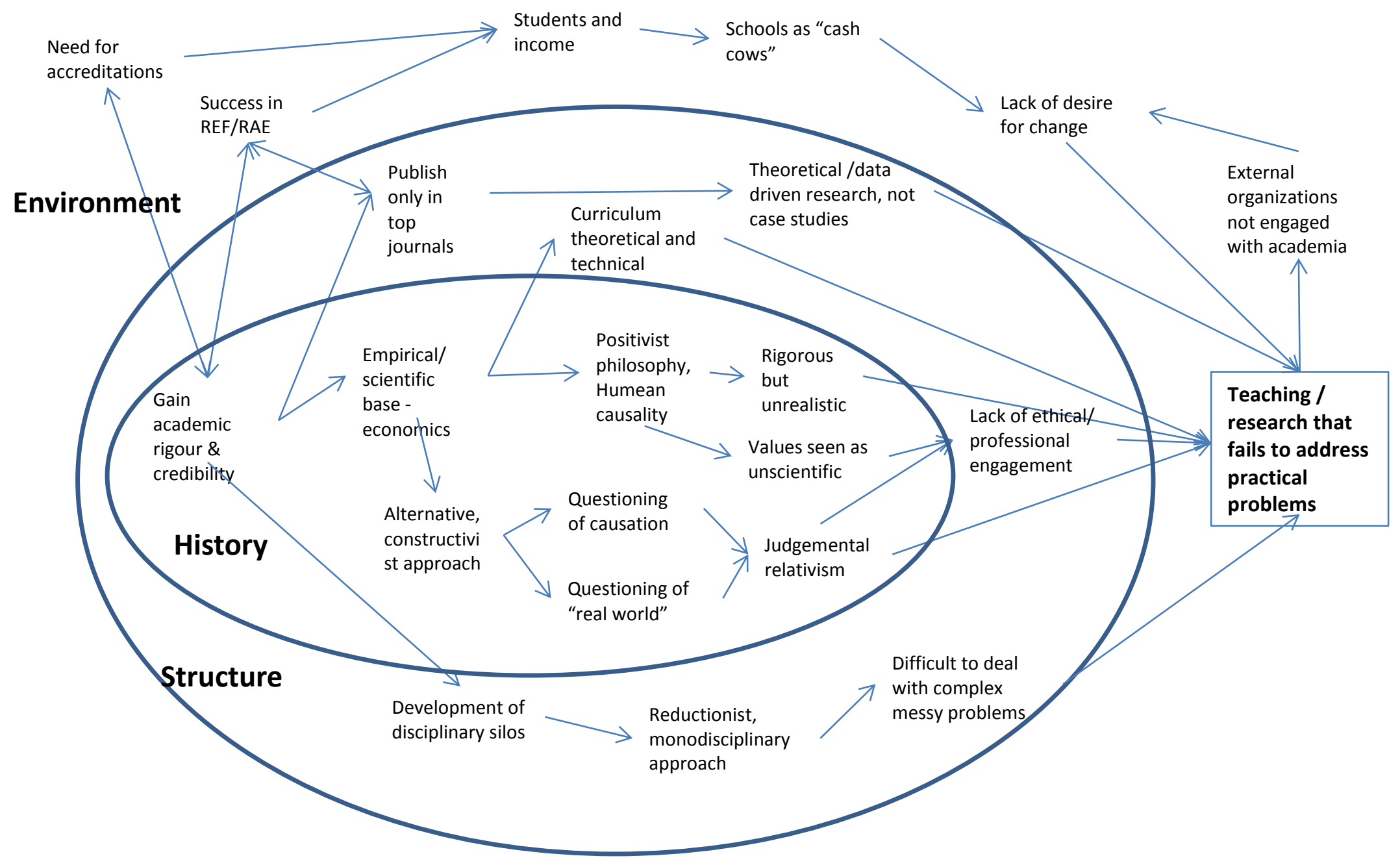

Figure 1 Influence Diagram of the Causes of a Lack of Practical Engagement 


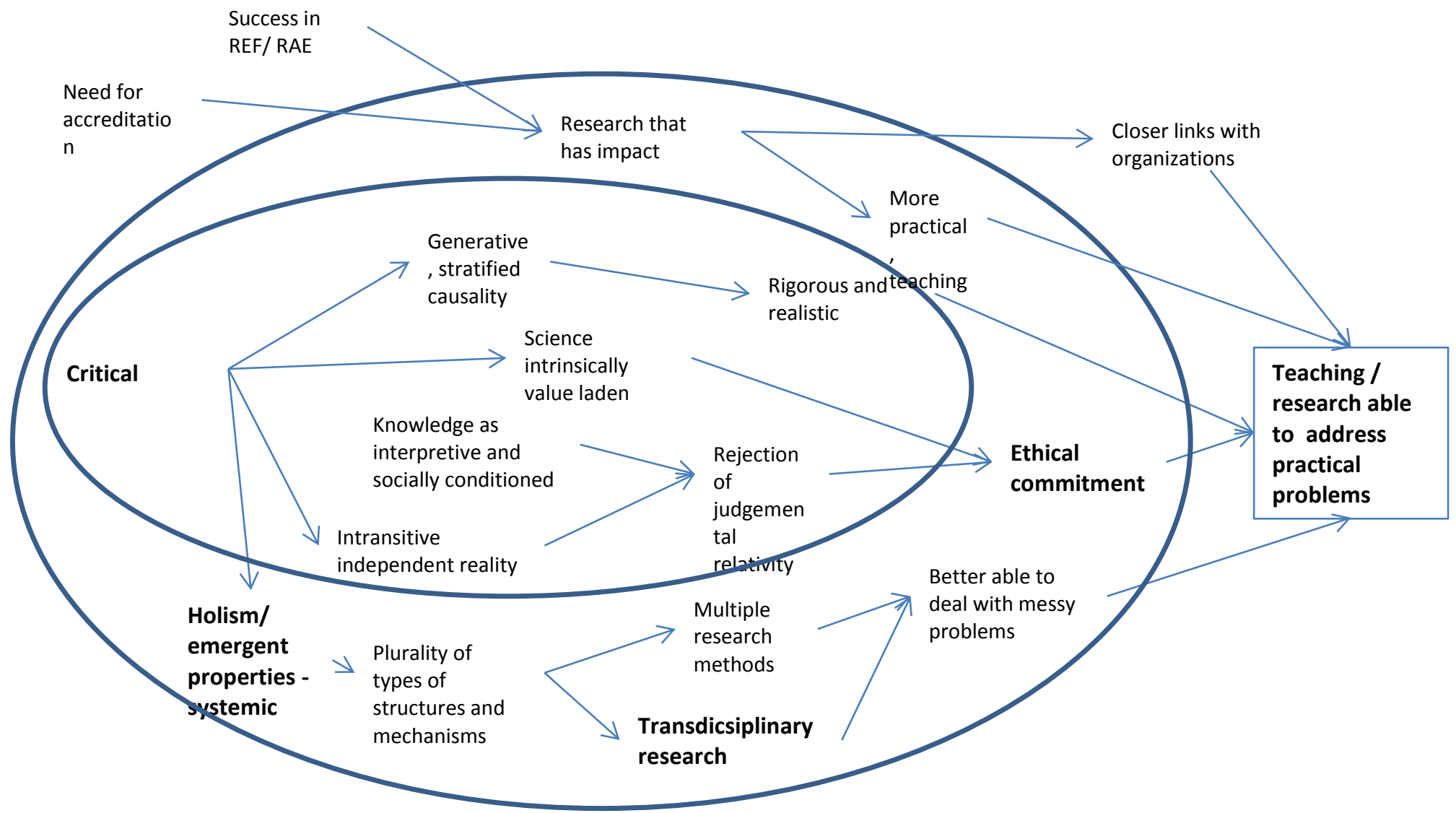

Figure 2 Influence Diagram redrawn to Show Potential Changes to the Situation 

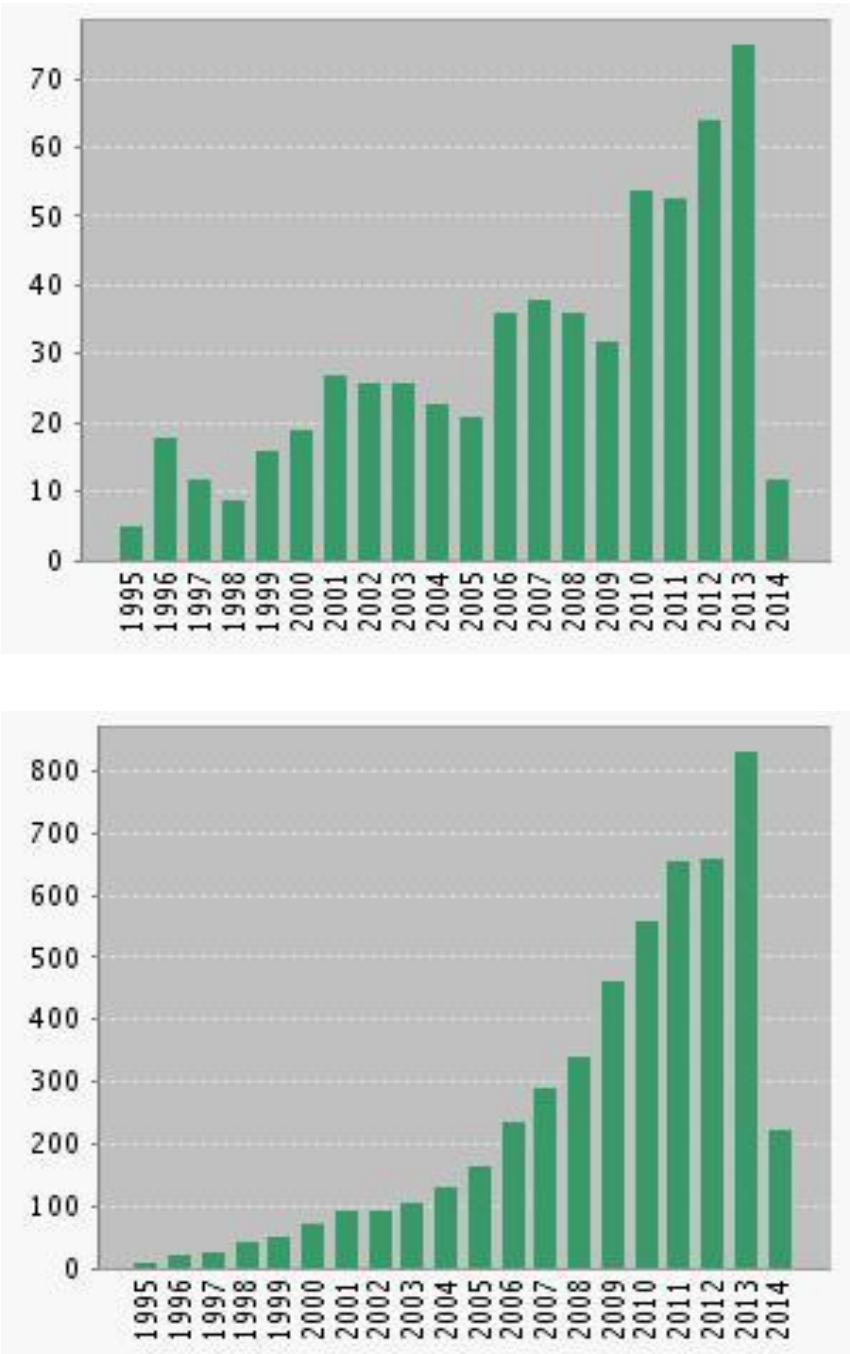

Figure 3 a) and b): The number of papers and the number of citations in WoS under the search term "critical realism or critical realist" in social science

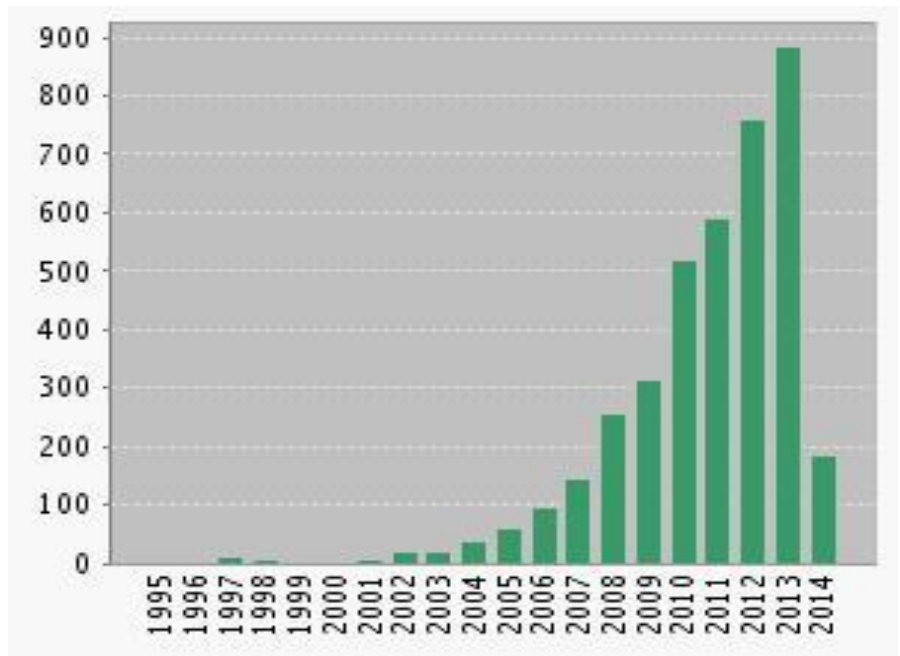




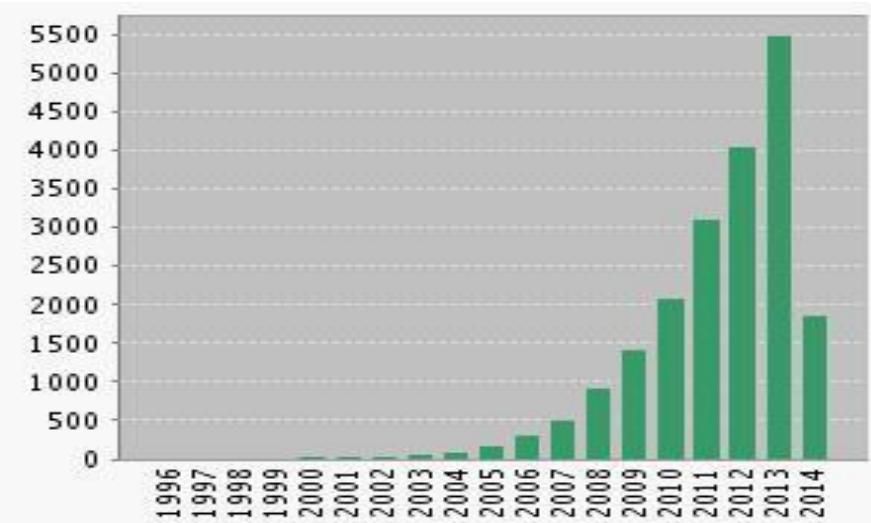

Figure 4 a) and b): The number of papers and the number of citations in WoS under the search term "mixed methods or multimethodology" in social science 